\title{
Volunteering Children: Parental Commitment of Minors to Mental Institutions
}

\author{
James W. Ellis*
}

In most states, ${ }^{1}$ parents may commit their children to mental institutions without a hearing or any other form of judicial scrutiny. If a parent wants a child committed, and a hospital will accept the child as a patient, no legal authority will hear the child's protest. Moreover, the child-patient has no standing to petition for release from the institution until he or she reaches the statutory age of majority. Until that time any request for discharge must be made by the parent. Thus

* Fellow at the Center for Law and Social Policy and the Mental Health Law Project, Washington, D.C.; B.A., Occidental College, 1968; J.D., University of Cahfornia, Berkeley, 1974.

1. This Article is concerned with the commitment of minors by their parents and guardians to mental institutions. The focus of the discussion will be on the commitment of mentally ill or emotionally disturbed children. References and analogy to the treatment of the mentally retarded will be noted.

The following statutes permit parents and guardians to commit minors voluntarily to mental institutions:

Alas. Stat. § 47.30 .020 (1970); ARIz. Rev. Stat. §§ 36-502, 36-504 (Supp. 1973); ARK. STAT. ANN. \& 59-405 (1971); CaL. Welf. \& INST'NS CODE $\$ 6000$ (West 1972); Colo. Rev. Stat. \& 71-1-2 (1963); ConN. Gen. STat. ANN. \$ 17-187 (Supp. 1972), § 17-234 (1960); D.C. Code ANN. \$§ 21-511, 21,512 (1973); FLג. STAT. ANN. $\S 394.465$ (1973); GA. CODE ANN. \$ 88.503.1, .2 (1971); HAWAI REV. STAT. § 33452 (1968); IdAHo Code ANN. \$\$ 66-318, 66-320 (1973); Ill. Stat. ANN. ch. 911/2, § 5-2 (Smith-Hurd Supp. 1973); Indiana Stat. ANN. § 22-1205 (Supp. 1973); Kan. Stat. ANn. \$§ 59-2905 to 59-2907 (Supp. 1973); KY. Rev. Stut. ANN. § 202.015 (1972); Me. Rev. Stat. ANn. tit. 34, \& 2290 (Supp. 1973); MD. ANn. Code art. 59, $\S 11(\mathrm{~g})$ (1972); MASS. GEN. LAWS ANN. ch. 123, §§ 10, 11 (Supp. 1973); Mich. Comp. Laws ANN. 330.19a (Supp. 1973); ANN. Mo. STat. \$\$ 202.783, 202.790 (1972); Mont. Rev. Codes ANN. § 38-406.2 (Supp. 1973); Nev. Rev. St八T. tit. 39, $\S 433.665$ (1973); N.H. Rev. Stat. ANN. 1964 §§ 135:22, 135:22-a (Supp. 1972); N.J. Stat. ANN. §§ 30:4-46, 30:4-48 (Supp. 1973); N.M. STAT. 1953 ANN. §§ 34-22, 34-2-4(2) (1953); N.Y. Mental Hygiene LAW $\$ 31.13$ (McKinney Supp. 1973); N.D. Century Code ANN. \$§ 25-03-01, 25-03-06(2) (1970); OHIo Rev. Code ANN. $\S 5122.02$ (Supp. 1973), § 5122.03(A)(2) (1970); OKLA. STAT. ANN. tit. 43A, § 184 (Supp. 1973); Ore. Rev. Stat. $\$ 426.220$ (1973); Pa. Stat. ANN. tit. 50, $\S \S 4402$, 4403 (1969); CODE OF LAwS OF S.C. 1962 \$ 32-951 (Supp. 1973); TENN. Code ANN. $\S 33-601$ (Supp. 1973); Utah Code ANN. $1953 \S 64-7-29$ (1961); VA. Code ANN. \$ 37.1-65 (Supp. 1973); Rev. CODE WASH. ANN. $\$ \$ 72.23 .070$ (Supp. 1973); W. VA. CODE ANN. \$§ 27-4-1, 27-4-3 (Supp. 1973); WIS. STAT. ANN. \$§ 51.10 (1957); WYo. STAT. §§ 25-54 (Supp. 1973). Challenges to some of these statutes are discussed infra, at notes 43-51, and 331-342. 
the minor admitted to a mental hospital on application of a parent is denied access to virtually all procedural protections-notice, hearing, appellate review, and habeas corpus-rights afforded all other patients institutionalized against their will.

\section{Development of Commitment Practices in the UNITED STATES ${ }^{2}$}

During the colonial and early national periods, allegedly insane persons were imcarcerated in jails and hospitals. Danger of injury to themselves or to the public furnished the legal grounds for commitment. Judicial reference to therapeutic considerations as grounds for commitment appeared first in the case of In re Joseph Oakes. ${ }^{3}$ In this 1845 Massachusetts case, Chief Justice Shaw endorsed the idea of involuntary commitment for the patient's benefit. ${ }^{4}$ His suggestion, however, was ignored by legislatures for a quarter of a century. In 1869, Isaac Ray, the leading American psychiatrist of his time, called for legislation to establish procedures and legal bases for commitment, arguimg that the common law decisions were confused and led to imconsistent results. ${ }^{5}$ He urged that new legislation be drafted to meet

Delaware and Texas require the child's consent for hospitalization. DeL. CODE AnN. tit. 16, § 5123(a)(c) (Supp. 1970); Tex. Civ. Stat. ANN. \$ 5547-23 (1958). Mississippi and South Dakota have no provision for voluntary hospitalization, and Vermont specifically excludes children from its voluntary commitment provision. VT. STAT. ANN. tit. 18, $\$ 7503$. Release of a child may be contingent on the consent of a parent or guardian. Id. at $\$ 8001$. The statutes of six states make no mention of age distinctions among voluntary patients. CODE of AlABAMA RECOMPILED 1958 tit. 45, \$205 (Supp. 1971); Iowa Code ANn. \$ 229.41 (1969); La. REv. Stat. ANN. 28:51 (1969); MinN. STAT. ANN. $\$ 253$ A.03 (Supp. 1974) (Until amended, effective Jan. 1, 1974, the Minnesota statute specifically required consent of the minor and parent or guardian. Minn. Stat. ANN. \$ 253A.03 (1971)); Rev. Stat. Neb. \$ 83-324 (1971); GEN. STAT. N.C. \$ 122-56.3 (1974); GEN. LAWs R.I. \$ 26-2-18 (1968).

The assistance of Miriam Rokeach in locating these statutes is gratefully acknowledged.

2. This subsection presents only a few incidents in the history of civil conmitment in this country. For a more thorough treatment of this subject see A. DEUTSCH, The Mentally Ill in America (2d ed. 1949). During the last decade, historians have devoted increasing attention to the history of mental ilhress and its treatment in American history. See, e.g., N. DAIN, CoNCEPTS OF INSANITY IN tHe UNITEd States, 1789-1865 (1964); G. GROB, MENTAL InstTtutions IN AMERICA: Social Policy to 1875 (1973) (the first of two projected volumes); G. GROB, THE STATE AND THE MENTALLY ILI: A HISTORY OF WORCESTER STATE HOSPITAL IN MASSACHUSETTS, 1830-1920 (1966); D. Rothman, The Discovery of THE AsyLum: Social ORDER aNd DISORDER IN THE NEW REPUBLIC (1971).

3. 8 Law Rptr. 122 (Sup. Jud. Ct. Mass. 1845) cited in N. KrtrRIe, The Right To Be Different: Deviance and ENForced Therapy 66 n.62 (1971).

4. N. Kittrie, The Right to be Different: Deviance and Enforced TherAPY 66 (1971).

5. Ray, Confinement of the Insane, 3 AM. L. REv. 193 (1869). 
three objectives: 1) prompt treatment beneficial to the patient, 2) protection of the privacy of those involved in commitment, and 3) protection of individuals from wrongful imprisonment. ${ }^{6}$ When the statutes were subsequently drafted, many' of them placed the strongest einphasis on Ray's third objective. This was due, in part, to the highly publicized case of Mrs. Dorothy Packard.

Mrs. Packard's liusband, a Calvinist preacher, had her committed in 1860 after she publicly disagreed with his theological views. Upon release, she became an energetic crusader for the rights of asylum ininates. She won passage of statutes providing jury trials for every patient already committed (in Illinois), recognizing the right to express insane-sounding opinions without fear of resulting commitment, (in Massachusetts), and establishing visiting committees, including female representation, to inspect insane asylums (in Iowa and Maine). In Washington, D.C. slie lobbied for congressional legislation to protect the postal rights of mental patients. Sle wrote and published MoDERN Persecution, OR Insane Asylums Unveiled, in seven volumes. Mrs. Packard's case and Charles Reade's 1863 novel Hard Cash, in which the young hero was committed by business associates seeking his inodest fortune, created support for legislation safeguarding the rights of persons faced with commitment proceedings. ${ }^{7}$

Prior to the growth of this sentiment, procedural requirements had been aimed primarily at excluding paupers and vagabonds from institutions, rather than at protecting sane persons from wrongful commitment. ${ }^{8}$ But in the late mineteenth century, the specter of "innocent" persons being railroaded into hospitals spurred the passage of restrictive commitment statutes. ${ }^{10}$ These laws typically tightened the definition of those who could be committed, and often provided procedural safeguards such as the right to jury trial in commitment proceedings.

A reaction against these statutes occurred in the 1940's and 1950 's, after psychiatry had finally attained stature as a profession.

6. Id. at 208.

7. Comment, Analysis of Legal and Medical Considerations in Commitment of the Mentally Ill, 56 YALE L.J. 1178, 1192 n.61 (1947) [hereinafter cited as Yale Comment]. See also, Dewey, The Jury Trial Law for Commitment of the Insane in Illinois (1867-1893), and Mrs. E. P. W. Packard, 1ts Author, 69 AM. J. INSANITY 571 (1913).

8. N. KITTRIE, supra note 4, at 64 .

9. The recurrent use of the term "imnocent" in the literature to describe sane persons is a puzzling phenomenon. For a discussion of innocence as a key to the selfimage of those who are mentally ill, see R. MAY, PowER AND INNOCENCE (1972).

10. N. KITTRIE, supra note 4, at 64 . Besides prescribing extremely formal procedures, these laws also had the effect of protecting hospital officials from charges of malfeasance and wrongful detention. Id. 
Psychiatrists argued that it was countertherapeutic to subject the mentally ill to humiliating and disturbing judicial hearings in which relatives and friends testified for commitment. ${ }^{11}$ Both psychiatrists and legal scholars argued that commitment laws created cumbersome and formalistic mechanisms ill-suited to the needs of the mentally ill and the standards of modern psychiatric practice. While arguing for statutory change, scholars dismissed popular fears of railroading as "the fancies of novelists and the delusions of the less than sane,"12 and sug. gested that society's obsession with the possibility of wrongful commitments was "a defense mechanism to rationalize our wretched neglect of those actually mentally ill." ${ }^{13}$ An influential Comment argued that the issues of legal competence and commitment had been confused, leading to a situation in whicl procedural rights, appropriately applied to protect the patient's property interests, were being imappropriately applied to the issue of commitment, which involved no "civil rights," only the question "whether a mentally sick person should be hospitalized."14 This movement for due process standards less rigorous than those applied in criminal cases led to statutory changes in many states includimg the abolition of jury trials and possible waiver of rights to notice and to be present at the commitment hearing when the exercise of those rights would be upsetting to the patient. There occurred a general shifting of the power to commit from judges to psychiatrists. ${ }^{15}$

Two conflicting values have dominated the debate on commitinent laws: the fear of wrongfully committing sane persons, and the desire to streamline commitment procedures in the interest of protecting the therapeutic process. Each viewpoint carries enormous emotional weight, and adherents on both sides are not particularly liappy with the involuntary commitment statutes now in force in most states. ${ }^{16}$ There is one developnent, however, whicl has been greeted enthusiastically by proponents of both viewpoints-the trend toward increasing voluntary admissions to mental hospitals. ${ }^{17}$ This phenonienon has

11. For a discussion of this issue, see text accompanying notes 255-264 infra.

12. Kadish, $A$ Case Study in the Signification of Procedural Due Process-Institutionalizing the Mentally Ill, 9 W. PoL. Q. 93, 103 (1956). (1953)

13. Curran, Hospitalization of the Mentally Ill, 31 N.C.L. Rev. 274, 293

14. Yale Comment, supra note 7, at 1189-90.

15. Some of these statutes have been declared nnconstitutional as violative of the due process clause of the fourteenth amendment. See, e.g., State ex rel. Fuller v. Mullinex, 364 Mo. 858, 269 S.W.2d 72 (1954).

16. N. KITTRIE, supra note 4 , at 83 .

17. The first voluntary admission statute was passed by Massachusetts in 1881 . Yale Comment, supra note 7, at 1201. As early as 1924, a major psychiatric journal had published an article advocating voluntary admission laws. Overholser, The Voluntary Admission Law: Certain Legal and Psychiatric Aspects, 3 AM. J. PsychiAtry 475 (1924). By 1939, 32 states had voluntary statutes, and by 1947, ten more states had 
been hailed by the "streamlining" advocates because it requires no legal procedure at all for a large and increasing number of patients, and by the "anti-railroading" advocates because it is presumed that railroaded persons would not consent to admit theinselves voluntarily. ${ }^{18}$ Voluntary admissions also allow treatment of mental illness at its earliest stages, before statutory requirenents for imvoluntary commitment are met, and before relatives feel forced to take the drastic step of sceking commitment. A person who voluntarily seeks hospitalization is also considered a more promising candidate for treatment since he or she has evidenced a desire to "get better." Finally, voluntary admission is desirable because it does not immediately place the patient in an adversary relationship with his family and with those who are about to provide treatment. ${ }^{19}$

II

\section{VOLUNTARY COMMITMENT OF JUVENILES}

In most states the new voluntary admission statutes did not include separate provisons for juveniles. As late as 1952, only nine states had laws allowing parents to voluntarily commit their children. ${ }^{20}$ The Draft Act Governing Hospitalization of the Mentally Ill proinulgated by the National Institute of Mental Health ${ }^{21}$ encouraged the trend, and today inost states permit "voluntary" commitment of children by their parents. ${ }^{22}$ The widespread adoption of these laws has been accompanied by an imcrease in the number of young mental pa-

adopted them. Yale Comment, supra note 7, at 1201. After promulgation of a Draft Act Governing Hospitalization of the Mentally III (Public Health Service Publication No. 51, 1951) [hereinafter cited as Draft Act], by the National Institutc of Mental Health in 1951, almost every state had some form of voluntary admission law. See note 1 supra. Among its other provisions, the Draft Act outlined a set of procedures to be followed in the hospitalization of voluntary patients-both adult and juvenile.

18. Kittrie notes that the distinction between voluntary and involuntary patients may be less than clear in many cases. N. KrTTRE, supra note 4 at 72. See also Gilboy, "Voluntary" Hospitalization of the Mentally Ill, 66 Nw. U.L. Rev. 429 (1971). See text accompanying notes 28-31 infra.

19. Proponents perceived one disadvantage with voluntary admission schemes: The patient, once admitted, might become restless or dissatisfied and walk out before treatment had begun. As a result most states adopted statutes providing that pationts admitted voluntarily could be held in the hospital for a specified period of time after giving notice of their intention to withdraw from the institution. E.g., CONN. GEN. STAT. ANN. \& 17-187 (1972) (ten day requirement). Thus, an adult voluntary patient who wishes to be released makes the request in the form of a "ten day notice." Under current statutes, juveniles can be released only after their parents have submitted such a notice. Id.

20. Weihofen, Hospitalizing the Mentally Ill, 50 MrcH. L. Rev. 837, 855-56 n.45 (1952).

21. See note 17 supra.

22. See note 1 supra. 
tients. For example, in 1954 the proportion of the California state hospital population under the age of 21 was 1.3 percent; in 1969, patients under 21 constituted 9.2 percent of the hospital population. ${ }^{23}$ Nationally, the number of hospitalized middle-aged patients has been decreasing while the number of patients between ages 15 and 24 has increased, the number of patients under age 15 increasing nost sharply. ${ }^{24}$

While research is not available to demonstrate the precise relationship between hospitalization rates and the availability of voluntary commitment procedures, it seems reasonable to conclude that the safeguards afforded adults who face commitment play a role in reducing the number of older persons so committed. Conversely, the ease with which parents can commit their children may well be related to the increasing number of young people in mental hospitals. At the very least, the "voluntary" commitment of children by their parents has created a large ${ }^{25}$ class of patients who, unlike involuntary patients, are unable to seek release, and who, unlike adult voluntary patients, lack the opportunity to leave. ${ }^{28}$

\section{A. The Distinctions Between Voluntary and Involuntary Commitment}

Despite alleged therapeutic advantages, ${ }^{27}$ several authors have questioned whether there is any difference in fact between a patient

23. CaI. Assembly Select Comm. on Mentally IIl and Handicapped ChilDREN, Report on SeRvices for the HaNdicapped AND MENTAILY Disordered CHIDREN 146 (1970).

24. Harris, Mental Illness, Due Process and Lawyers, 55 A.B.A.J. 65, 67 (1969).

25. It is difficult to find accurate figures for the number of young mental patients, and impossible to find a breakdown of how they were committed. Perhaps the most realistic estimate of the total figure is 33,000 children in pnblic and private mental hospitals and another 26,000 in residential treatment centers. Ginsberg, An Examination of the Civil Rights of Mentally Ill Children, 52 CHILD WELFARE 14, 15 (1973).

26. This paper will deal only with juveniles who are admitted as voluntary patients, and will not focus on the situation of those children who are involuntarily coinmitted, for whatever reason, under normal commitment procedures. However, some parents pass up the easier voluntary route. In New York, for example, the demand for admission is so great in some of the children's urits of state hospitals that children will not be admitted unless they are judicially certified (committed) when they first enter. The Special Committee to Study Commttment Procedures of the Association of the Bar of the City of New York, Mental Illness and Due Process 75 (1962) [hereinafter cited as NEw YoRK BAR].

27. Some of the advantages which have been claimed for voluntary admission procedures have been discussed above. See text at notes 16-19, supra. Proponents also argue that nurses and attendants often find voluntary patients inore attractive than those involuntarily committed. Since voluntary patients are thought to have recognized the need for treatment and initiated the process, they are considered easier to work with. These staff attitudes can have a positive impact on a patient's self-inrage and 
who is voluntarily admitted and one who is involuntarily committed. A voluntary patient may have agreed to hospitalization because of the threat of involuntary proceedings, family pressure, or exploitation of his or her lack of information. ${ }^{28}$ Discussing the attorney's function in commitunent cases, Professor Fred Cohen argues that one cannot take the passivity commonly observed in prospective patients "to be a meaningful acceptance of commitinent." ${ }^{29}$ Thomas Szasz, noting that voluntary patients can be held against their will for the length of a statutory notice period-during which time they can be converted to involuntary status by the imitiation of commitinent proceedings, concludes that "[t]ruly voluntary hospitalization is virtually nonexistent in public inental imstitutions in the United States." ${ }^{30}$ Professor Nichols Kittrie casts further suspicion upon the distinction by noting that a patient committed involuntarily may not have been subjected to any compulsion, nor objected to the commitment; involuntary commitinent may simply imply a lack of volition on the part of the patient." It has been suggested that the term "non-protesting admission" inore accurately describes the situation of a person who neither seeks nor opposes hospitalization.

Important differences in the rights a patient enjoys do depend on which side of this distinction he or she falls. The first of these differences is the level of mental illness which will bring about hospitalization. Under most statutes, a voluntary patient may be adinitted if he or she and the admitting physician agree that hospitalization would be beneficial. A inore rigorous standard, dangerousness to oneself or to others, is sometimes applied in cases of involuntary coinmitment." Necessary and desired treatinent should not be denied a person just because he or she is not ill enough to be involuntarily committed. Nor should relatives or the state have the power to commit a person because treatment might be beneficial.

It has been suggested that commitment statutes should contain two different standards to govern these disparate circuinstances:

on the success of his or her treatment. Denzin and Spitzer, Patient Entry Patterns in Varied Psychiatric Settings, 50 Mental Hygiene 257 (1966). For these reasons, the law has been urged to encourage voluntary admissions, and hospital personnel who refuse to accept voluntary patients have been vigorously criticized. Blackley, Judicial Intervention as a Psychiatric Thearpy Tool, 15 Clev.-MAR. L. Rev. 506, 513 (1966); NEw YoRK BAR, supra note 26, at 75 n.26.

28. Roth, Cut Through the Looking Glass, 3 Rough Times 9 (Nov. 1972).

29. Cohen, The Function of the Attorney and the Commitment of the Mentally Ill, 44 TEX. L. REv. 424, 447 (1966).

30. T. SZASZ, LAW, LIBERTY, AND PSychiatry 40, 83 (1963).

31. N. KITTRIE, supra note 4 , at 72.

32. Some states allow the involuntary commitment of persons in need of treatment, whether dangerous or not. See text accoinpanymg notes 366-67 infra. 
Cure is at best difficult with an unwilling patient. Compulsory process must be reserved only for those who pose a likelihood of danger to life or property. Although the need for early treatment, before an individual becomes a source of danger, is acknowledged, such treatment should be accomplished through the encouragement of truly voluntary hospitalization or ambulatory treatment in community clinics. ${ }^{33}$

Given these assumptions, it is difficult to argue that minors should not be allowed to initiate their own treatment. But under voluntary admission statutes, even a minor meeting the lower voluntary admission standard may only seek care through parental application.

Another important legal implication of the voluntary-involuntary distinction is the right of voluntary patients to be released after giving the statutorily required notice. ${ }^{34}$ Voluntary adult patients who have given notice cannot be detained unless hospital officials convince a court that the patient meets the standards for involuntary commitment. An involuntarily committed adult patient may seek release in the courts through habeas corpus or through the periodic review of commitments which is required by some statutes. ${ }^{35}$ Here, as in juvenile court waiver proceedings, "the child receives the worst of both worlds." 38 The child cannot give notice of an intention to leave without approval of the parents who sought the initial commitment, and there are no legal grounds upon which to challenge hospitalization unless the voluntary commitment statutes themselves are challenged. Short of bringing suit on constitutional grounds or seeking favorable statutory construction, the juvenile patient who seeks discharge has no recourse except to those who agreed to the original hospitalizationparents and hospital authorities. ${ }^{37}$ Here the child's position bears no resemblance to that of either the adult voluntary or involuntary patient; rather, it is umiquely restrictive.

Some statutes provide rights to involuntary patients which are denied to voluntary patients, imcluding juveniles. New York's law provides that involuntary patients are entitled to automatic periodic

33. N. KrTTRIE, supra note 4, at 100-01. See also Comment, Hospitalization of the Mentally Disabled in Pennsylvania: The Mental Health-Mental Retardation Act of 1966, 71 Dick. L. REv. 300, 307 (1967) [hereinafter cited as Dickinson Comment].

34. See note 19 supra.

35. Most periodic review statutes place the burden of proof on the hospital to show the need for continued hospitalization, but a few are modelled on habeas corpus proceedings, and place the burden on the patient to show sanity and harmlessness. B. Enmis \& L. Siegel, The Rigrtss of Mental Patients 46 (1973). See also text at notes 359-60 infra.

36. Kent v. United States, 383 U.S. 541, 556 (1966).

37. Dickinson Comment, supra note 33, at 313. 
review of their commitment. ${ }^{38}$ In addition, the Mental Health Information Service ${ }^{39}$ is notified of each patient's commitment and is charged to study and review both admission and retention. The statute does not extend these rights to voluntary patients. With In re Buttonow, ${ }^{40}$ New York's highest court held that a patient who had been transferred from involuntary to voluntary status by hospital authorities was deprived of both due process and equal protection, and was therefore entitled to a hearing on her suitability to be a voluntary patient. Beheving in the benefits of voluntary hospitalization, the court stopped short of calling all such transfers unconstitutional. Still, the majority's language and construction of the statute suggest that similar voluntary-imvoluntary discriminations may be suspect:

"A narrow, illiberal reading of the statute would leave a voluntary patient without a disinterested review of his detention, would deprive him of judicial and other valuable protections afforded involuntary patients and, by reason of that, deny him constitutional rights to which he is entitled." 11

But tens of thousands of children "voluntarily committed" face these very disabilities.

\section{B. Legal Challenges to Juvenile Voluntary Status}

Juveniles admitted to hospitals by their parents under voluntary admission statutes have the rights of neither voluntarily nor involuntarily committed adult patients. ${ }^{42}$ Before proceeding to further analysis of what their legal status is and what it should be, notice will be taken of recent challenges to voluntary juvenile admissions. Recently, legal challenges have begun to exact some recogmition of children's rights.

38. N.Y. MENTAL HyGIENE LAW \& 31.35 (McKinney Supp. 1974).

39. Note, The New York Mental Health Information Service, 67 Colum. L. Rev. 672 (1967). See Litwack, The Role of Counsel in Civil Commitment Proceedings: Emerging Problems, 62 Cax.r. L. Rev. 816 (1974) (this issue).

40. 23 N.Y.2d 385, 244 N.E.2d 677, 297 N.Y.S.2d 97 (1968).

41. Id. at 393, 244 N.E.2d at 681,297 N.Y.S.2d at 103.

42. In view of the lack of juvenile patients' rights generally, mention should he made of one statute which purports to give special treatment to young patients. When Pennsylvania revised its commitment statute in 1966, it removed a section of the 1951 Act which provided that a juvenile voluntary patient could not be held more than 30 days without obtaining a court order. PA. STAT. ANN. tit. 50, $\$ 1164(a)$ (1) (Supp. 1965). While the new Act has no such provision, it does provide that the voluntary patient who is a minor is to be advised every 60 days that he is a voluntary patient. Adult patients are not so advised. Mental Health Act of 1966, \& 402(d). One author has noted the absurdity of informing juvenile patients (who cannot leave without parental application) of their "right to leave," while not so informing adult patients, who arc free to leave. Dickinson Comment, supra note 33, at 314. 
In In re $\mathrm{Lee}_{,}{ }^{43}$ the Illinois voluntary admission statute ${ }^{44}$ was challenged on due process and equal protection grounds. Plaintiffs weie wards of juvenile court, having previously been adjudicated neglected, and the state, acting in locol parentis, ${ }^{45}$ had the children admitted to hospitals. The court did not reach the constitutional arguments of plaintiffs, but construed the statute to permit juvenile patients to seek and obtain their own release without parental consent.

A Connecticut court recently reached a similar result in the case of Melville v. Sabbatino. ${ }^{46}$ The court held that since persons between the ages of 16 and 18 could apply for their own hospitalization and release under Connecticut's statute, logic required that persons in that age group have the right to sign theinselves out of a hospital even if their parents had signed them in. ${ }^{47}$ While the Melville holding is limited to the release of einancipated 16- and 17-year-olds under the state statute, the court's opinion makes clear that even the cornmitment of unemancipated minors by their parents would be subject to the due process requireinents ${ }^{48}$ of In re Gault. ${ }^{49}$

Tennessee's statute permitting the voluntary commitnent of inentally retarded children by their parents was recently struck down by a three-judge federal court. In Saville $v$. Treadway, ${ }^{50}$ the court noted the possible conflict of interest between the parents and the inentally retarded child, and held that the lack of procedural safeguards in the juvenile voluntary commitment procedure violated the due process clause of the fourteenth amendment. ${ }^{51}$

43. No. 68 (JD) 1362 (Cook County Cir. Ct., Juv. Div., IIl. Feb. 29, 1972) $a b-$ stracted in 6 Clearinghouse Rev. 284 (Aug.-Sept. 1972). No. 68 (JD) 1362 (Cook County Cir. Ct., Juv. Div., Ill. Aug. 24, 1972) (ordering the preparation of plans for placement of discharged children and requiring monthly reports evaluating each ward's progress) abstracted in 6 CleARINGHOUSE REv. 575 (Jan. 1973).

44. ILL. REv. STAT. ch. 911/2, \$§ 5-1 through 5-3 (1969).

45. While this fact may have blunted potential family-privacy arguments in defense of the statute, it did not figure overtly in the argument or decision of the case.

46. 30 Conn. Supp. 320 (Super. Ct. 1973), also reported at 42 U.S.L.W. 2242 (Nov. 6, 1973).

47. 30 Conn. Supp. at 325.

48. Id. at 322 .

49. 387 U.S. 1 (1967). Similar constitutional issues have been raised against Pennsylvania's voluntary juvenile commitment provisions in Bartley v. Haverford State Hospital, a class action brought on behalf of a number of juvenile patients, in which a three-judge federal court is being asked to find that the commitment and release provisions of the statute deprive young patients committed by their parents of both due process and equal protection. No. $72-2272$ (E.D. Pa., filed November 16, 1972). The complaint and plaintiffs' memorandum of points and authorities are cited at 6 CLEARINGHOUSE REv. 640 (Feb. 1973).

50. - F. Supp. - (M.D. Tenn., Civil Action No. 6969, March 8, 1974).

51. While Saville dealt with the commitment of mentally retarded children, the constitutional issues do not differ greatly froin those presented by the case of parental commitment of mentally ill juveniles. 
Challenges to statutes providing for the voluntary commitment of juveniles by their parents are likely to increase in the near future. Courts have shown great interest in both juvenile rights ${ }^{52}$ and the rights of mental patients ${ }^{63}$ in recent years; the confluence of these two concerns makes this a likely setting for judicial scrutiny. Given the artificiality of the voluntary-involuntary distinction, and the fact that children are denied the rights of both adult classes, convincing arguments will have to be advanced in defense of a system which allows juvenile patients so few civil biberties. ${ }^{54}$ The remaining sections of this Article will examine some important considerations regarding the juvenile commitment systein, and propose an alternative statutory framework in which young people are accorded a larger role in the commitment decisions which affect their own lives. Attention will be focused upon the roles of parent, psychiatrist, child, and attorney.

\section{III}

\section{The Parent: Emerging Limitations on the Parental Role}

\section{A. The Decision to Commit}

The significance of the role parents play in the commitment of children is difficult to overstate: The parent alone may seek hospitalization and release of the child. Presently the only limitation on parental discretion is the requirement of concurrence by the committing authority, usually the administrator of the hospital or the admitting physician. These officials frequently fail to exercise independent judgment, however, generally deferring to the wishes of the parents. ${ }^{55}$ Many institutions nay investigate a proposed commitment no further than the information supphed by the family of the proposed patient. ${ }^{50}$

Probably, few parents are guilty of railroading their children into

52. E.g., In re Gault, 387 U.S. 1 (1967); Kent v. United States, 383 U.S. 541 (1966).

53. E.g., Jackson v. Indiana, 406 U.S. 715 (1972); Baxstrom v. Herold, 383 U.S. 107 (1966).

54. There are three justifications that could be used for forcing hospitalization on young patients who would not be subject to such commitment if they were adults. (1) Children are not old enough to make a mature judgment about whether they need treatment or not, and therefore someone else must make it for them. (2) Children are subject to the decisions made for them by their parents, and a commitment decision is within the scope of parental authority. (3) Mental disorders are much more tractable when the patient is young, and therefore there is a greater state interest in forcing treatment on mildly ill young persons than on mildly ill adults.

55. See text accompanying notes $132-44$.

56. Even where the psychiatrist does not make a conscious decision to defer to the family's judgment, the home atmosphere influences the diagnosis and recommendation. For a discussion of the psychiatrist's role, see text accompanying notes 132-64 infra. 
asylums in the manner that spurred nineteenth-century reform movements. Still, the emergence of a countercultural lifestyle among young people in recent years, and the troubled reaction of some parents lends support to the suggestion that some parents have resorted to voluntary commitment procedures in order to sanction behavior of which they disapproved. ${ }^{57}$ Parents may be confused, bewildered, and saddened by what they perceive as their child's "crazy" behavior. ${ }^{58}$ In individual cases there 1nay be some validity to the parents' belief in a connection between acceptance of countercultural styles and einotional difficulties, but parents' own visceral reaction to the different lifestyle may color their diagnosis. ${ }^{59}$ Where parental action does result im unjustified commitment, it is probably not due to malevolence or filial hatred but to a feeling more akin to irritation or embarrassment over the child's unconventional behavior. ${ }^{60}$ The level of irritation or embarrassment can become acute and reach a level where parents become desperate. ${ }^{61}$

Since parents make the decision to commit their child at a time of great emotional stress, the decision may be made without a careful consideration of possible alternatives. ${ }^{62}$ The availability of alternatives is in large part determined by the socioeconomic status of the

57. B. ENNIS \& L. SIEGEI, supra note 35 , at 38.

58. These observations reflect the author's experience of working with adolescent patients and their parents at the Yale Psychiatric Institute, New Haven, Connecticut, from August 1969 to August 1971. It has been noted that the motives of parents seeking the institutionalization of their retarded children include the interests of other children in the family, the mental and physical frustration of the parents, economic strain resulting from caring for the child at home, the stigma of retardation, hostility resulting from the burdens of caring for the child, the parents' success-oriented expectations of the child, and the advice of doctors who are ignorant of other treatment possibilities. Murdock, Civil Rights of the Mentally Retarded, 48 NotRE DAMR LAw. 133, 139 (1972). Many of these same factors may motivate parents who seek to have a child hospitalized as mentally ill.

59. Cf. In re Smith, 16 Md. App. 209, 295 A.2d 238 (1972), holding that a parent could not force her unmarried 16-year-old daughter to have an abortion.

60. Yale Comment, supra note 7, at 1182-83.

61. Letter from Elizabeth Strutzel (Clinical Specialist, Yale Psychiatric Institute) to the Calmornia LaW ReviEw, March 30, 1973.

62. Provision of impartial, expert psychiatric counseling might mitigate this problem, but parents rarely have access to this form of advice. A survey of parents of children at Napa State Hospital's children's unit, for example, indicated that the decision to commit the child was influenced by private physicians or psychiatrists in only $36 \%$ of the cases. Probation officers, welfare workers, and public school officials influenced $73 \%$. CoMm. ON MENTAily Ill aNd Handicapped ChIIDREN, Report ON SERvices For tHe HANDICAPPEd AND MENTALIY DISORDERED CHIIDREN 227 (1970). See also Kay, Farnham, Karren, Knakal \& Diamond, Legal Planning for the Mentally Retarded: The California Experience, 60 CALIF. L. REv. 438, 516 (1972). While private physicians are not uniquely qualified to advise parents on possible alternatives, institutional officials may not have the time or motivation to seek out "less restrictive alternatives" to hospitalization. 
family. While no studies have been found which focus on the relationship of social class to early or late hospitalization, it has been observed that upper-middle-class families have access to alternatives short of hospitalization-such as special schools, long vacations, and private psychiatric treatment-which are not available to families from lower socioeconomic groups. ${ }^{63}$ The poor, when faced with acute family problems, do not have recourse to these facilities; they also have the least access to informed assistance in making decisions involving their child's illness and possible commitment.

\section{B. Parental Authority and Family Privacy}

Thomas Szasz argues that a source of parental power is the law's interest in shoring up the imstitution of the family, and that hospitalization serves this interest by reducing family tensions "without disrupting the moral integrity of the family as an institution." ${ }^{44}$ Thus, unlike the social institutions of divorce and separation, commitment maintains the legal structure of the family, and promotes the illusion that nothing is irremediably wrong with the relationships involved. Szasz concludes:

Thus, for the individual, involuntary hospitalization ensures the maintenance of the family as a good institution. For society, it ensures the maintenance of family relationships, loyalties, and responsibilities as positive moral values. Our whole social system needs the safety valve that commitment laws provide. Without it, our traditional ideas about the duties and rights of family meinbers would have to be reexamined, reassessed, and changed. ${ }^{65}$

One does not have to share Szasz's ideology ${ }^{66}$ to agree that commitment laws, and juvenile commitment provisions in particular, have as their paramount objective the mamtenance of family autonomy in dealing with aberrational behavior within the family. As a result, the authority granted to parents in the area of commitment to mental hospitals is extremely broad. Can such a broad grant of power be justified? To justify such an extensive grant of power, supporters of broad parental prerogatives point to analogous areas of the law and argue that the state should continue to decline to intrude into the parent-child relationship.

63. T. LIDZ, S. Fleck \& A. Cornellison, Schizophrenia AND tHe FAMILY 131 (1965) [hereinafter cited as T. LIDZ]. See generally A. HollingsheAd \& F. Reduicri, Social Class and Mental Illness (1958); Weihofen, Mental Health Services for the Poor, 54 CALIF. L. REv. 920 (1966).

64. T. SZASZ, supra note 30 , at 154 .

65. Id.

66. E.g., T. SzASz, The MYTH of Mental IlLness (1961). 


\section{The Constitutional Framework}

Adherents to the belief in parental control within the family may rely on a line of United States Supreme Court decisions dealing with parent-state relationships. In Meyer $v$. Nebraska, ${ }^{67}$ the Court held unconstitutional a Nebraska statute forbiddimg the teaching of any subject in a language other than English, ${ }^{68}$ and the teaching of any language other than English in the first eight grades of school. In Pierce $v$. Society of Sisters ${ }^{69}$ the Court struck down an Oregon statute requiring parents and guardians of children between the ages of eight and sixteen to send them to public schools. The Court noted:

The fundamental theory of liberty ... excludes any general power of the State to standardize its children by forcing them to accept instruction from public teachers only. The child is not the mere creature of the State; those who nurture him and direct his destiny have the right, coupled with the high duty, to recognize and prepare him for additional obligations. ${ }^{70}$

The Court preserved the authority of parents and guardians to direct the upbringing and education of their children.

While numerous decisions have upheld parental power as against the state, this power is not without constitutional limits. In Prince $v$. Massachusetts, ${ }^{71}$ the guardian of a nine-year-old child was convicted of violating state child labor laws by furnishing a child with magazines, knowing that the child would sell them unlawfully, and by permitting a child in her custody to "work" contrary to law. ${ }^{72}$ The guardian and child were Jehovah's Witnesses and had been distributing copies of Watchtower and Consolation, engaging in what they considered to be religious duty. ${ }^{73}$ The Court noted that the recognition of parental prerogatives in Pierce had been founded on the notion of family privacy protected from state intervention, and then added:

But the family itself is not beyond regulation in the public interest .... Acting to guard the general interest in youth's well being, the state as parens patriae may restrict the parent's control by requiring school attendance, regulating or prohibiting the child's labor and in many other ways..$^{74}$

67. 262 U.S. 390 (1923) (reversing the conviction of a teacher, using the substantive due process analysis of that era).

68. The state court construed the statute as not proscribing Latin, Greek, or Hebrew. Id. at 400-01.

69. 268 U.S. 510 (1925).

70. Id. at 535 .

71. 321 U.S. 158 (1944).

72. Id. at 160 .

73. Id, at 161-63.

74. Id. at 166 (footuotes omitted). 
While the Court may continue to regard the exercise of parental discretion as an important interest, under certain conditions strong public policy may also require that parental discretion be limited.

\section{Parental Tort Immunity}

One crystalization of the noninterventionist policy of the state is the parental tort immumity doctrine. Not recognized at common law, it is a modern statutory creation intended to protect the parent-child relationship as "a umique kind of social unit different from all other groups."75 The notion that immunity helps to preserve family harmony has been attacked by many commentators. Dean Prosser disparaged parental immunity as based "on the theory that an uncompensated tort makes for peace in the family and respect for the parent, even though it be rape or a brutal beating, and even though the relation itself has been terminated by death before the suit."70 While the doctrine is not dead, it is clearly on the decline; courts have either abolished it outright or weakened it by an increasing number of exceptions. ${ }^{77}$

While it seems unlikely that voluntary commitment of children by their parents will lead to tort suits by children against parents, ${ }^{78}$ the parental immunity doctrine is nevertheless illuminating as an example of the family privacy notion under which courts decline to imvolve themselves in disputes within the family umit. ${ }^{79}$ Although many courts have retreated from specific extensions of this policy, the basic reluctance remains, and must be overcome if courts are to take an active part in limiting parents' rights to place their children in mental hospitals. In attempting to persuade judges to abandon their reticence, support can be drawn from a variation on Prosser's observation: Family tranquility and the parent-child relationship will already have been disrupted both by the child's behavior and by the parents' decision to seek commitment, which implies that they can no longer cope with the situation. Judicial nonintervention supports the integrity

75. Badigian v. Badigian, 9 N.Y.2d 472, 174 N.E.2d 719, 215 N.Y.S.2d 35 (1961); overruled by Gelbman v. Gelbman, 23 N.Y.2d 434, 245 N.E.2d 192, 297 N.Y.S.2d 529 (1969).

76. W. PROSSER, LAW OF TORTS 866 (4th ed. 1971).

77. Kleinfeld, The Balance of Power Among Infants, Their Parents and The State, pt. II, Parental Power, 4 FAM. L.Q. 410, 427 (1970) [hereinafter cited as Kleinfield II].

78. It is of historical interest to note that the parental immunity doctrine was first expounded in an 1891 suit by a Mississippi child against her parents for false imprisonment in an insane asylum. Hewellette v. George, 68 Miss. 703, 9 So. 885 (1891).

79. J. Goldstein, A. Freud \& A. Solntr, Beyond The Best Interests of The CHILD 50 (1973). 
of the family unit only in the sense that it allows the parents in a dysfunctional family to deny the existence of real family problems by "blaming" them on the illness of one of their children. ${ }^{80}$

\section{Consent to Medical Treatment}

Consent for surgery and other medical treatment is a widely recognized parental prerogative. While the cases which most strongly support parental power in this area involve very young children, ${ }^{81}$ it is nevertheless thought to be the general rule that in determining the need for surgical or hospital treatment, the personal consent of the child need not be obtained. ${ }^{82}$ In certain circumstances, however, judicial limitations have been placed upon parental discretion-not so much in the form of recognition of objections by the child, as in giving effect to the state's interest as parens patriae. ${ }^{83}$ For example, where the parents' religious beliefs prevent the child from receiving needed medical treatment, the state may take custody of the child in order to provide that treatment. ${ }^{84}$ While the body of case law on consent to surgery and other medical treatment does not explicitly recognize a new role for children, the limitation of parental power in the name of the state may have the practical effect of upholding the child's interest.

The parens patriae doctrine allows courts to adjust the parentchild relationship in order to prevent harm to the child. Parens patriae should, at a minimum, permit courts to review parental discretion in commitment cases where wrongful and unnecessary confinement may also prove very damaging to the child. ${ }^{85}$ Courts have ordered psychiatric treatment for children over the objection of their parents. ${ }^{86}$ It seems inconsistent to mamtain that courts do not have authority to prevent or terminate such treatment where it can be shown to be inappropriate.

80. See text accompanying notes $112-27$ infra.

81. E.g., Weston's Adm'x v. Hosp. of St. Vincent, 131 Va. 587, 107 S.E. 785 (1921); Friedrichsen v. Niemotka, 71 N.J. Super. 398, 177 A.2d 58 (1962).

82. 59 Am. Jur. 2d Medical Care $\$ 15$ (1971). See also Bonner v. Moran, 126 F.2d 121 (D.C. Cir. 1941) (consent of a 15-year-old boy held not a valid defense to an assault and battery action).

83. Cf. Wisconsin v. Yoder, 406 U.S. 205, 233-34 (1972).

84. People ex rel. Wallace v. Labrenz, 411 IIl. 618, 104 N.E.2d 769 (1952), cert. denied, 344 U.S. 824. Cf. In re Hudson, 13 Wash. 2d 673, 126 P.2d 765 (1942) (holding that a court cannot order a surgical operation over parental objection unless the parents are found unfit). Other courts, as in Labrenz, equate refusal to allow the operation with parental unfitness.

85. Cf. Matter of Seiferth, 309 N.Y. 80, 86, 127 N.E.2d 820, 823 (1955) (Judge Fuld dissenting).

86. E.g., In re Wcintraub, 166 Pa. Super. 342, 71 A.2d 823 (1950). 


\section{Incorrigibility Laws}

Courts have also had to deal with strongly entrenched parental power in interpreting laws dealing with what are variously terined stubborn, beyond-control, or predelinquent children ${ }^{87}$ Of course most of the means parents use to obtain the obedience of their children do not directly involve public law. ${ }^{88}$ But at a certain level of disobedience, the state is willing to intervene in support of parental decisions. The developinent of intervention laws accoinpanied the growth of the juvenile court system in the beginning of this century, ${ }^{80}$ the rehabilitative goals of the child-saving movenent were thought to be best served by gaining control over a child before he or she committed acts which would be declared criminal. ${ }^{00}$ Court action in beyond-control cases often results in taking custody of the child from the parents, because they can no longer control the child's actions." Beyond the immediate purpose of stabilizing what may be an emergency situation for the child, the ultimate goal of incorrigibility statutes is to shore up the family's controls, which have broken down. ${ }^{02}$ But while the aim of these laws is the establishment of family cohesiveness, Professor Aidan Gough argues that they often accomplish precisely the opposite: by institutionalizing the child or otherwise removing him from the family setting, the laws defeat their own purpose by shifting the focus away froin the family and its problems. ${ }^{03}$ In re Henry G., ${ }^{0.4}$ a recent California case in which a mother sought to have her son adjudicated beyond parental control, held that the juvenile court in such cases must conduct an investigation thorough enough to enable the court to determine whether the child's behavior is merely a "manifestation of intra-family parent-child conflict;" lowed to show that the breakdown of parental control results from the parents' failings rather than the child's. Henry $G$. contrasts with the usual presumption of incorrigibility laws: that a failure of family dis-

87. For an indication that these laws have venerable predecessors-and interesting doctrinal origins-see Rotenberg and Diamond, The Biblical Conception of Psychopathy: The Law of the Stubborn and Rebellious Son, 7 J. HIST. Bennv. ScI. 29 (1971).

88. Kleinfeld II, supra note 77, at 424-25.

89. Cf. id. at 434-35.

90. The President's Commission on Law Enforcement and the Administra-

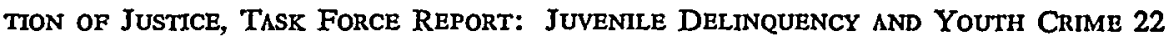
(1967). See also A. Platt, The Chimd Savers (1969).

91. E.g., CAL. WELF. AND INST'NS CODE $\$ 601$.

92. Gough, The Beyond Control Child and the Right to Treatment, 16 ST. Louis L.J. 182, 197 (1971).

93. Id. at 190-92, 195. See discussion of pathology in the family accompanying notes 120-35 infra.

94. 28 Cal. App. 3d 276, 104 Cal. Rptr. 585 (2d Dist. 1972).

95. Id. at 285, 104 Cal. Rptr. at 591. 
cipline can only be cured by blaming it on the child and removing him or her from the family. Gough's criticism of beyond-control laws is also applicable to a system which responds to family disruption by allowing parents to "expel" an aberrational child from the family into a mental institution.

\section{Potential Conflicts of Interests}

Cases of beyond-control children exemplify the essential conflict of interests between parents and their children. Where' the parent is the complainant against an allegedly disobedient child, courts have recognized that the interests of the parents and child, at least for the purposes of the proceeding, are in potential conflict. For example, in Marsden $v$. Commonwealth ${ }^{96}$ the Massachusetts Supreine Judicial Court held that due process, as interpreted in Gault, required that the accused child be provided with separate counsel. Even before Gault, courts had recognized that there were some situations in which the interests of parents and child were in conflict, both in certain financial transactions ${ }^{97}$ and in cases of alleged incorrigibility. For example, In re Sippy, ${ }^{98}$ in which a mother charged her 17-yearold daughter with being habitually beyond her control, ${ }^{99}$ held that the mother could neither control her daughter's legal representation nor waive the doctor-patient privilege for her. ${ }^{100}$ Both rulings were based on the adversary role the parent assumed by entering the complaint in the commitment proceedings. Sippy teaches that where a parent seeks to liave a child committed to a hospital, the law's customary deference to the judgment of the parent cannot be allowed to obscure the fact that the parent and child may have opposing interests, and that to entrust the child's procedural and substantive rights to the parent effectively abolishes those rights.

The recognition by some courts that incorrigibility proceedings create a conflict of interest between parent and child has not led to the repeal of beyond-control statutes. But questions have been raised about the appropriateness of the behavioral standards which such laws enforce. Professor Gough has pointed out that the law traditionally views incorrigibility cases in terms of the gap between the child's behavior and the parent's standards, and merely assumes that the parent's

96. 352 Mass. 564, 227 N.E.2d 1 (1967).

97. E.g., White v. Osborne, 251 N.C. 56, 110 S.E.2d 449 (1959) (held that failure of father to prosecute appeal as "next friend" was not binding on the child in a tort action where the interests of father and child conflicted).

98. 97 A.2d 455 (D.C. Mun. Ct. App. 1953).

99. The charge was brought one month before the daughter became eighteen, the statutory limit in such cases.

100. 97 A.2d at 457 . 
standards are the same as those of society. ${ }^{101}$ These same assumptions are reflected in the voluntary juvenile commitment system. In beyond-control cases, Gough suggests that "[w]here the behavior of the child diverges from the standards of the family, but does not clearly threaten the community norms, it can be said to fall within minimally acceptable, though not necessarily desirable, limits and should not afford the court coercive jurisdiction."102

Gough further suggests that beyond-control cases present an ap. propriate area for the application of the developing doctrine of the right to treatment, ${ }^{103}$ and that it should run to both parents and children. This doctrine, whicl had its origins in the area of civil commitments, essentially holds that persons detained against their will on purportedly therapeutic grounds must be given effective treatment or released. ${ }^{104}$ But the right to treatment does not necessarily imply a duty to submit to treatment. ${ }^{105}$ We are beginning to see the first hints of a corollary right which might be called the right to refuse treatment. ${ }^{106}$ If, as Gougli argues, the right to treatment sliould run to both the parent and child where the person detained is a minor sliould the right to refuse treatment also be exercisable by botll? Judicial recognition of the child's right to refuse treatment might be based upon due process, as is the riglit to treatment, ${ }^{107}$ and upon the devel-

101. Gough, supra note 92, at 187.

102. Id. at 187-88.

While the state has taken the parents' side on the parental discipline issue by enacting and enforcing incorrigibility laws, it has also placed limits on the means which parents can use-the child abuse statutes. Such laws typically measure child abuse in terms of the injury, danger, or suffering inflicted upon the child, and provide stiff criminal penalties for parents who have overstepped the bounds of "acceptable" disciplining of children. E.g., CaL. PeNal CODE $\$ \S 273($ a), 273(d). In contrast, child neglect and dependency laws usually empower the juvenile court to remove the child from the home, but stop short of criminal penalties for the parents. E.g., CAL. WELF. \& INST'NS CODE $\$ 600$. It has been argued that the key difference between child abuse and neg. lect is the element of dehberateness. S. KATZ, When Parents FaIL: THe LAw's RESPONSE TO FAMIIY BREAKDOWN 22 (1971).

103. Id. at 194.

104. Rouse v. Cameron, 373 F.2d 451 (D.C. Cir. 1967).

105. Katz, The Right to Treatment-An Enchanting Legal Fiction?, 36 U. CH. L. REv. 755, 762 (1969).

106. Relying on various constitutional grounds, courts have upheld a right to refuse treatment in a number of recent cases. Mackey v. Procunier, 477 F.2d 877 (9th Cir. 1973) (experimental drugs); Winters v. Miller, 446 F.2d 65 (2d Cir. 1971) cert. denied, 404 U.S. 984 (1971) (tranquilizing medication); Stowers v. Ardmore Acres Hosp., 19 Mich. App. 115, 172 N.W.2d 497 (1969) (involuntary hospitalization); New York City Health and Hospitals Corp. v. Stein, 335 N.Y.S.2d 461 (Sup. Ct. 1972) (electroshock treatmeut); Kaimowitz v. Dep't of Mental Health of Mich., Civ. No. 7319434-AW (Cir. Ct., Wayne County, Mich. July 10, 1973) reported in 5 ClearinoHOUSE Rev. 302-03 (Sept. 1973) (psychosurgery).

107. Rouse v. Cameron, 373 F.2d 451, 453 (D.C. Cir. 1966). 
oping constitutional right to privacy. ${ }^{108}$ If the basis is due process, the adversary nature of the parent's and child's interests would prevent the parent from constitutionally exercising the child's right. The privacy doctrine has not been developed as fully, but the Supreme Court has made clear that it is essentially an individual right, ${ }^{109}$ and therefore its exercise by a parent in opposition to the wishes of the child, or the granting of a parental veto over the child's ability to exercise it, would contradict the spirit of a privacy based right to refuse treatunent. Gough has identified the key question by asking, "Has the parent a right distinctly and separately cognizable from the right of the child?"110 In juvenile voluntary commitments, no less than in beyond-control cases, courts are faced with problems of family conflict and disruption presented by parents and children who have opposing legal interests. ${ }^{111}$

\section{Patholgy in the Family}

Often the problems which lead parents to seek hospitalization of their child can be traced to family difficulties and not just the "illness" of an imdividual child. ${ }^{112}$ A number of psychiatrists and other mental health professionals now treat troubled families as units, ${ }^{113}$ and theorists have developed a number of concepts to explain the forces at work when family cohesiveness breaks down so dramatically that parents seek to commit their children to mental hospitals. ${ }^{114}$

\section{Scapegoating}

It has been observed that soine parents transmit their own inadequacies and conflicts to the weakest child in the family, and thus in-

108. See, e.g., Griswold v. Connecticut, 381 U.S. 479 (1965); Roe v. Wade, 410 U.S. 113, rehearing denied, 410 U.S. 959 (1973); Doe v. Bolton, 410 U.S. 179, rehearing denied, 410 U.S. 959 (1973).

109. Eisenstadt v. Baird, 405 U.S. 438, 453 (1972).

110. Gough, supra note 92, at 187.

111. "To assume that the family's and patient's interests are always, or nearly always, compatible is to ignore the realities of family strife. At times it is one's family against which one needs the most protection." N. KrrTrIE, supra note 4, at 86.

112. T. Lmz, supra note 63 .

113. Group for the Advancement of Psychiatry, Treatment of Famities in CONFLICT (1970).

114. These concepts are usually found in studies which purport to explain the causes of mental disorder, in particular, schizophremia. It is beyond the scope of this paper to discuss the relative merits of the various theories regarding the etiology of schizophrenia. The empirical studies conducted by adherents of the theory that schizophrenia originates within the structure of the patient's family present useful data for an understanding of the processes of such families, whatever their etiological value. The purpose of discussing them briefly here is solely to examine the situation within the family which immediately precedes commitment. 
duce that child to live the role of one who is mentally ill. ${ }^{115}$ Some indication of the prevalence of scapegoating is presented by a Philadelphia prehospitalization study which showed that in 25 percent of the complaints of alleged mental illness, it was the complainant, rather than the prospective patient, who evidence signs of mental illness. ${ }^{110}$ It is even theorized that in some families, when the scapegoated member's induced deviance becomes so pronounced that he or she must be hospitalized, the family process creates a new scapegoat, and another family member takes up the deviant role. ${ }^{117}$ Clearly the existence of scapegoating in a family will mean that isolated treatment of the child will not solve the problem; the pressures to act deviantly will continue with any family contact, and may resume in full force if the patient returns to the family setting after discharge. The focus of therapy must be on the family situation. In some cases acceding to the parent's request for commitinent of the child may only reinforce the scapegoating mechanism and confirm to the child that his or her deviant behavior is a result of personal inadequacy. ${ }^{118}$

\section{Pseudo-Mutuality}

Another key concept is pseudo-mutuality, ${ }^{110}$ the development of a veneer of intense affection accompanying interactions between family members which masks the true feelings persons in the family have for one another. Pseudo-mutuality may be accompanied by a faulty communication system within the family, which confuses messages be-

115. Vogel \& Bell, The Emotionally Disturbed Child as the Family Scapegoat, in A Modern InTroduction to the Family $412-427$ (N. Bell \& E. Vogel eds. rev. ed. 1968).

Eric Bermann, an authority on family interaction, has documented one such case: as the father of an eight-year-old boy lay dying, the family unconsciously selected the boy as the "expendable" family member who was to serve as a seapegoat. The family was unable to deal openly with the collective guilt and terror caused by the father's illness, and instead projected those feelings into the behavior of the child. $E$. BERMaNN, SCAPEgoat: The IMPact of DEATH-Fear on aN AMERICAN FaMiLy (1973).

116. T. Scheff, Being Mentally Ill: A Sociological Theory 171 (1966).

117. N. Ackerman, Treating the Troubled Family 85 (1966); cf. Jackson \& Yalom, Conjoint Family Therapy as an Aid to Intensive Psychotherapy, in THERAPY, Communication, and Change 169, 170 (D. Jackson ed. 1968); T. Lidz, supra note 63, at 236-61. A growing field within child psychiatry is beginning to examine what makes some children more vulnerable than others. THE ChILd IN His FaMily: ChildREN AT PSYCHIATRIC Risk (E.J. Anthony \& C. Koupernik eds. 1974).

118. Recognition of family pathology and the parental role in dysfunctional families has led some courts to require family therapy in cases of child abuse. Sec, HeLPING THE BatTered Child and His Family (C.H. Kempe \& R. Helfer eds. 1972); Steele \& Pollock, A Psychiatric Study of Parents Who Abuse Infants and Small Children, in The Battered CHILD 103-47 (R. Helfer \& C.H. Kempe eds. 1968).

119. Wynne, Ryckoff, Day \& Hirsch, Pseudo-Mutuality in the Family Relations of Schizophrenics, 21 PSYCHIATRY 205 (1958). 
tween family members and thus inhibits the working out of internal problems. ${ }^{120}$ These circumstances can make it difficult for an outsider to assess the family situation. It may be difficult to perceive the turbulent family dynamics if the presentation by family members gives evidence of nothing by sweetness, light, and good feeling all around. Whether the misinformation and imadequate intrafamily communication are based upon pathology in other family inembers or in the dynamics of the group process itself, the result is the same-a family situation in which it is impossible for an "insider" to objectively decide whether another family inember requires hospitalization.

\section{Treatment and the Family}

Whatever the cause of the disruption, ${ }^{121}$ the difficulties of the child often cannot be differentiated from the disorder within the family. ${ }^{122}$ Szasz suggests that mental illness is often merely a label to describe a person's failure to fulfill certain family obligations and expectations. He argues that the decision whether to commit a person is less a matter of medical treatment than it is a moral clioice between competing values-' "the integrity of the family or the autonony of the individual." 123 In the case of voluntary juvenile commitments, the law distorts the choice between family integrity and personal auton-

120. The classic case of such a confusing message is the "double bind." See, T. LIDZ, supra note 63, at 171-78. Social psychologists have found that even in a nonfamily group situation, such faulty communication can lead to the expulsion of a deviant group member. Lemert, Paranoia and the Dynamics of Exclusion, 25 SOcloMETRY 2 (March 1962).

121. It is at least theoretically possible that those who ascribe individual mental disease to family pathology may have the causation reversed; the disruption in the family may be caused, in whole or in part, by the disruptive presence of the mentally ill child in the family. An eminent psychoanalyst has observed:

We distort the situation if we abstract it in such a way that we consider the parent as "having" such and such a personality wheu the child is born and then, remaining static, impinging upon a poor little thing. For this weak and changing little being moves the whole family along. Babies control and bring up their families as much as they are controlled by them; in fact, we may say that the family brings up a baby by being brought up by him.

E. ERIKSON, ChILdhood aNd Society 69 (2d ed. 1963). Erikson views biological factors as "potentialities for changing patterns of mutual regulation." Id.

The child's power within the family continues into the treatınent process, whatever the etiology of the problem may have been. This Comment focuses on the power of the parents, since it is parental authority which is enforced by the state. But attorneys involved in juvenile commitment cases should be aware that the child may also have a great deal of psychological power within the family. Probably the strongest weapon in the child's arsenal is the ability to make the parents feel guilty. See generally B. Bursten, The Manipulator: A Psychoanalytic View (1973).

122. It has been observed that symptoms are neither normal nor abnormal in and of themselves; they derive their clinical importance from the situation in which they occur. T. SCHEFF, supra note 116 , at 172.

123. T. SzASZ, supra note 30 , at 154 (emphasis omitted). 
omy, for it bases its choice on the perception of the family situation held by one part of the family-the parents. R.D. Laing has written, "We can never assume that the people in the situation know what the situation is. A corollary to this is: the situation has to be discovered."124 In the case of juveniles, the law's method of discovery is, in effect, a conclusive presumption that the parents' perception is correct. The greatest drawback accompanying this presumption is that parents often cannot assess their own role in family problems. If the child in a family is disturbed, the parents may be the disturbing agents. ${ }^{125}$

Even from the perspective which views the family as the most effective unit of treatment, the commitment of children by parents is not always without therapeutic value. Parental consent to hospitalization may be a step toward involving parents in a treatment program for the child and the family, and may have a positive impact on the child's own approach to therapy. ${ }^{126}$ But recognition of the therapeutic importance of the parents' agreement to, and participation in, the treatment of a disturbed child need not compel acceptance of the omnipotent role which the law currently gives to parents in deciding whether to hospitalize the child. Parental involvement can-and should-be obtained by means short of giving the parent absolute discretion. And in many cases, giving the parents such discretion may have the effect of allowing the parents to withdraw from the troubled situation by using the child's exclusion from the family as a means of denying their own contribution to the problen and not recogmizing the need for change on the part of all family members. ${ }^{127}$

\section{An Appropriate Role for Parents in the Commitment Process}

What should be the parents' role in a new legal framework for the hospitalization of mentally ill children? The first parental function

124. R.D. LAING, Intervention in Social Situations, in THE PoLrTICS OF THE FAMIIY AND OTHER ESSAYS 33 (1971) (emphasis omitted).

125. "There is no systematic psychoanalytic theory of the nature of transpersonal defences, whereby self attempts to regulate the inner life of the other in order to preserve his own, nor of techniques of coping with such persecution by others." Id. at 13. Psychiatry's failure in this regard is evidenced by the fact that there are "clinical terms for disturbed, but not for disturbing persons." R.D. LAING \& A. EsTERSON, SANITY, MADNESS AND THE FAMILY 149 (1964).

126. Letter from Elizabeth Strutzel, supra note 61.

127. Some families not only postpone recognition of the problems faced by the family until the intensity of family distress becomes unbearable, but also continue some pretense of denial even after a member has been hospitalized. This has been observed in families whose equilibrium depends upon the balancing influence provided by the "sick" member's illness. T. LIDZ, supra note 63, at 274.

One group of commentators has noted that it is often a shift in the family equi- 
will continue to be diagnostic. Parents (and to a certain extent schoolteachers) will be the persons most likely to observe disturbed behavior at an early stage, and will continue to be the persons most likely to refer the child for professional diagnosis and treatment. ${ }^{128}$ However, the advantage of proximity to the child does not necessarily give parents the expertise or objectivity required to make a determination of the precise nature of the problem or to decide whether hospitalization is a necessary or desirable response. Thus the parent may remain the initiator of the inquiry into the child's situation, but should not retain the power to conduct that inquiry alone or to decide on the final disposition.

A second parental function may, in some cases, include personal involvement in the treatment process. This may take the form of individual counseling or therapy for one or both parents, work with a psychiatric social worker, conjoint family therapy insolving both the child and the parents, or a combination of these and other treatment approaches. Depending upon the kind of treatment which the child, and perhaps other family meinbers, are to undergo, parents may also be asked or required to contribute financially to the cost of the hospitalization. ${ }^{129}$ Depending upon the child's age and the family situation at the time of his or her release from the hospital, the family may also be called upon to take the child back into the home when treatment is completed. But none of these admittedly important functions requires that parents decide whether the child should be hospitalized. They are often ill-equipped to nnake that decision by themselves. A legal framework must be devised which will infuse expertise and objectivity into a function which the parents now exercise alone.

\section{IV}

\section{The Psychiatrist: A Check on Parental Discretion?}

It is often argued that even if the parent's authority to commit children to mental hospitals is excessive, the admitting psychiatrist ${ }^{120}$

Iibrium which necessitates hospitalization of a family member-either because it renders that member more disturbed, or because the family can no longer provide care-rather than a fundamental change in his or her medical condition. Id.

128. The parents' role in diaguosis has been exaggerated by some who claim that it is exclusive. For example, the argumeut of counsel in Van Deusen v. Newcomer, 40 Mich. 90, 102 (1879), was that, "The disease is often so obscure and subtle as to be detected only by the near relatives; those who discover differences in the patient not open to the observation of a stranger or a casual acquaintance."

129. Even where minors can be admitted on their own application, hospitals may require that the parents assume financial responsibility. V. VICTOROFF \& $\mathrm{H}$. Ross, HOSPITALIZING THE MENTALLY ILL IN OHIO 49 (1969).

130. For the purposes of this paper, unless otherwise stated, the term "psychia- 
will act as a check against ill-advised parental action. No figures are available to indicate how frequently psychiatrists deny parental requests for the commitment of children on the grounds that the request is inappropriate. Experience shows that in the most blatant cases of parental error psychiatrists do screen out admissions which are not warranted by apparent pathology in the child. ${ }^{131}$ In less obvious cases, however, psychiatrists may fail to perform an effective screening function. There are three reasons for this failure: (1) The performance of psychiatrists in precommitment interviews and examinations is often perfunctory and tends toward overdiagnosis; (2) Psychiatrists may be insensitive to legally important commitment issues; (3) The effectiveness of the psychiatrist in the admitting process is weakened by uncertainty over whose agent he or she is in such circumstances-the parent's or the child's.

\section{A. Psychiatric Inexactitude, Overdiagnosis, and Perfunctory Performance}

After a thorough study of the processes by which persons are committed to mental hospitals, Professor Cohen concluded:

Civil commitment proceedings are . . . characterized by mutual expectations of perfunctory performance. No pressure for the alteration of role and function is exerted from the formal participants-the judge, the attorney, the psychiatrist, or the proposed patient. All seem content to go through the empty ritual of the hearing and resist any temptation to indulge in self-evaluation. ${ }^{332}$

It is difficult to generalize about the intensity of the precommitment psychiatric investigation, ${ }^{133}$ but in hospitals with inadequate professional staffing the process inay mvolve only a short interview with the parents and perhaps with the child. Few institutions can afford to conduct a detailed investigation of the family background or the results of previous attempts at treatnent. ${ }^{134}$ Thus, in many cases, even with

trist" shall be used generally to refer to all professional personnel-including psychologists, psychiatric social workers, psychiatric nurses, etc.-who may have some responsibility for screening commitments to mental hospitals. While the differences between the functions of these professionals are important, they are beyond the scope of this paper. See, Comment, Underprivileged Communications: Extension of the Psychotherapist-Patient Privilege to Patients of Psychiatric Social Workers, 61 CaLfr. L. REv. 1050 (1973).

131. The author's experience suggests that the level of scrutiny given to these parental requests varies from psychiatrist to psychiatrist and from institution to institution.

132. Cohen, supra note 29 , at $A 48$.

133. Mishler \& Waxler, Decision Processes in Psychiatric Hospitalization, 28 AM. Sociological Rev. 576 (1963).

134. See, e.g., B. ENNIS \& L. SIEGEL, supra note 35 , at 28. 
the best of motives, the psychiatrist will be contributing to a momentous decision on the basis of incomplete information.

There are other factors which may lead psychiatrists to conclude incorrectly that a child or adolescent requires hospitalization. ${ }^{135}$ Thomas Scheff believes that overdiagnosis is a pattern which reflects a value judgment within the inedical profession that it is better to err on the side of caution, assuming disease rather than health. Scheff notes that while this will not usually cause irreversible harm in cases of assumed physical illness, it will result in deprivation of liberty where mental illness is overdiagnosed. ${ }^{136}$ One commentator has observed that caution can further distort the diagnostic function when it is accompanied by a gloss of professional certainty, which leads doctors to assume an "apostolic function," and to manipulate the patient so that he or she manifests the disease which the doctor has diagnosed. ${ }^{137}$ It has also been noted that tendencies toward overdiagnosis nay be inost pronounced when the patient is a child..$^{138}$

Dr. David L. Rosenhan recently conducted an experiment in which eight normal persons, "pseudopatients," presented themselves for voluntary admission at twelve different hospitals. ${ }^{139}$ The only synntoin the pseudopatients pretended to exhibit was hearing voices saying something like "empty" or "thud." ${ }^{40}$ In every case, the pseudopatient was admitted to the hospital with a diagnosis of schizophrenia or manic-depressive psychosis. Of particular interest is a follow-up experiment in which staff members at a research and teaching hospital were told to be watchful for possible pseudopatients presenting theniselves for admission. Of the 193 patients evaluated, 41 were identified, with a high degree of confidence, as pseudopatients by at least one staff member, and 23 were so identified by at least one psychiatrist. In fact, there were no pseudopatients in the group of 193. Rosenhan concludes that "any diagnostic process that lends itself so readily to massive errors of this sort cannot be a very reliable one." 141

Overdiagnosis is not necessarily indicative of any lack of integrity in the psychiatric profession. It nray be a function of the caution which is an essential part of medical training. ${ }^{142}$ It may also reflect

135. See Ennis \& Litwack, Psychiatry and the Presumption of Expertise: Flipping Coins in the Courtroom, 62 CALIF. L. REv. 693 (1974) (this issue).

136. T. SCHEFF, supra note 116 , at 105-21.

137. M. Balint, The Doctor, His Patient, and the Illness 216 (1957), cited in T. SCHEFF, supra note 116, at 178.

138. T. SZASZ, THE MANUfacture OF MAdNESS 35 (1970).

139. Rosenhan, On Being Sane in Insane Places, 179 SCIENCE 250 (1973) (reprinted in 13 Santa Clara Law. 379 (1973)).

140. Id. at 252 .

141. Id. at 252 .

142. Id. 
a desire to avoid any possibility of self-destructive behavior on the part of the child being examined. ${ }^{143}$ But whatever its sources, overdiagnosis leads not just to inaccuracies but to the wrongful confineinent of those young people whose situations do not require hospitalization. Because psychiatric knowledge about funotional mental disorders is "clinical and intuitive, and thus not subject to verification by scientific methods," ${ }^{144}$ it should not be surprising that diagnosis is less than precise. This inevitable inprecision lends support to the conclusion that the liberty of children accused of mental illness by their parents should not rest in the hands of psychiatrists alone.

\section{B. Psychiatric Attitudes Toward Legal Aspects of Commitment}

An indication of the attitude of the psychiatric profession toward legal safeguards in commitment cases may be found in Henry Davidson's popular text FoRENSIC PsYCHIATRY, ${ }^{145}$ which argues that procedural safeguards developed in the criminal law to guarantee due process are inappropriate for use in involuntary commitment proceeding; of mental patients. Davidson views the medical considerations as fundamental, and as incoinpatible with various procedural requirements. He argues that we cannot have it both ways; either we treat commitment as a medical problem, and do away with such features as notice to the patient, or we treat it as a legal problem and subject the patient to procedures which may be against his or her best medical interests. ${ }^{146} \mathrm{Dr}$. Davidson's views on notice requirenents may reflect the uneasiness with which some psychiatrists view the necessity of confronting the patient with the reality of confinement:

To psychiatrists, perhaps the most infuriating of the legal features of commitment is the requirement that notice be given to the patient. . . . If the patient is already in a hospital on a temporary, voluntary, or emergency paper, the ward physician has the unen-

143. See generally R. SeIden, SuIcide Among Youth (1969) (U.S. Public Health Service Publication No. 1971). Psychiatrists may similarly overpredict dangerousness to others when examining mental patients, but the problem is most acute in the difficult to define area of "dangerousness to oneself." Dershowitz, The Psychiatrist's Power in Civil Commitment, 2 Psychology Today 43 (Feb. 1969). Professor Dershowitz cites numerous examples to show how hard it is to define the precise meaning of danger to oneself, including the following limerick:

My doctor has made a prognosis

The Lament of a Coronary Patient

That intercourse fosters thrombosis

But I'd rather expire

Fulfilling desire

Id. at 46 .

Than abstain, and develop neurosis.

144. T. SCHEFF, supra note 116 , at 7 .

145. H. DAVIDSON, Forensic Psychiatry (2d ed. 1965).

146. Id. at 282 . 
viable task-in many states-of facing the patient and telling him that steps have been initiated to declare him "insane." "147

There is certainly little appreciation in the statement just quoted for the role of the patient in the making of the commitment decision, much less the therapeutic importance of dealing with the prospective patient honestly. Such attitudes toward legal requirements may be stated in a more sympathetic fashion, ${ }^{148}$ but however they are expressed, ${ }^{149}$ the sentiments suggest that psychiatrists, even with the best of good will, are ill equipped to play the judge's role in the commitment of an unwilling juvenile. ${ }^{150}$ In the case of adult commitments, the law has devised machinery by which both concerns-medical and legal-can be expressed in the decision making process. In the case of juvenile commitments, if non-medical considerations are to be taken into account, at present it must be done sua sponte by the admitting physician. This double burden is one that psychiatrists should not be required to shoulder. ${ }^{151}$

\section{The Psychiatrist as Double Agent ${ }^{152}$}

The traditional position of the psychiatric profession is that the psychiatrist is the agent of the patient, and will act only on his or her behalf. When a parent seeking to have a child committed goes to a hospital official or a private psychiatrist, however, the psychiatrist's position becomes less clear-cut. In the case of a juvenile voluntary

147. Id. at 229-30. This uneasiness may in turn encourage practices by which minors are lured into hospitals under a veil of parental lies ("It's only for some tests").

148. E.g., a leading text on psychiatry contains this description of the relationship between lawyer and psychiatrists:

One of the important differences between the psychiatrist and the lawyer is in their respective attitudes toward the admission of the mentally ill person to a hospital. The psychiatrist urges that the dignity of the patient be respected and that the obstacles to his admission be no greater than those experienced by the physically sick person. ... [T] ance of what it regards as human rights. . . . The lawyer should not be criticized too severely for his vigilant solicitude for the legal rights of the individual. The physician believes, however, that one's medical rights are no less fundamental than his legal rights, and that the sick person should not be subjected to heartless and harmful inental torture imcident to commitment.

L. Kolb, Noyes' Modern Cuinical Psychiatry 606 (7th ed. 1968).

149. Psychiatrists may also express their lack of concern for non-inedical considerations by simply ignoring the subject. T. SzASz, supra note 30 , at 41 .

150. Dershowitz, supra note 143 , at 47 .

151. Oran, Judges and Psychiatrists Lock Up Too Many People, 7 Psychorogy Today 20, 27 (Aug. 1973). Cf. Cohen, supra note 29, at 456.

A more adversary proceeding would also provide a challenge to commitment examinations and the tendency to overdiagnose. See text accompanying notes 132-44 supra.

152. The concept of the psychiatrist as a double agent (where the bind is between the patient and the state) is discussed in S. Halleck, THE Politics of Therapy 119. 25 (1971). 
patient, the legal volition involved is that of the parent. While the goal of the psychiatrist will be expressed-and perceived-as the best welfare of the child-patient, it is the parent who las come to seek help, whose situation seems most desperate, who seems the most reliable source of information about what is wrong, who is closest to the psychiatrist in age and social outlook, ${ }^{153}$ and who is paying the psychiatrist's fee. Sociologist Thomas Scheff reports an interview with one committing physician who observed: "[The family request cases are] pretty automatic. If the patient's own family wants to get rid of him you know there is something wrong." 154 It is not clear how many psychiatrists loold such a view, but even where the physician does a more independent evaluation, it may be difficult to disentangle the problems of the individual child from the context of the family setting.

Whenever it arises, overidentification with the parent ill equips the psychiatrist to function as a check on the desire of the parent to hospitalize the child. The effect may be that the admitting or certifying psychiatrist becomes-often unwittingly-the agent of the parent in the parent-child confrontation.

\section{Early Discharge, An Inadequate Remedy for Improvident Commitment}

It is sometimes argued that even if the psychiatrist is ineffective as a check on parents seeking commitment, any error will be rectified by hospital personnel who will quickly recognize and release a child who does not require hospitalization. This argument fails to take into account the realities of institutional practice. The inpersonal nature of day-to-day hospital operation inakes immediate identification unlikely. The hospital staff may not be oriented toward recognizing the absence of pathology. ${ }^{165}$ And even if the child is released soon after admission, it cannot be said that no harm has been done.

\section{Institutional Considerations}

Institutional contingencies which play an inportant part in determining whether a patient is released range from the number of beds available in the hospital to policy regarding release of the marginally ill. Some hospitals have an unofficial policy of retaining patients

153. A recent study by a noted political scientist found that nearly two-thirds of the public hospital psychiatrists surveyed believe that the typical American family is too lenient with children. A. Rogow, The Psychiatrists 185 (1970).

154. T. ScheFF, supra note 116, at 147. Scheff describes another psychiatrist who recommended a thirty day commitment for a patient whom he thonght not to be mentally ill. The young patient was having difficulties with his parents, and the doctor felt he "might get into trouble." Id.

155. Rosenhan, supra note 139. 
whose medical condition might merit release until someone in the community expresses willingness to take responsibility for them. ${ }^{156}$ In cases of very young and very old patients, "commumity acceptance" often means the willingness of the patient's family to take him or her into the family home. Since voluntary juvenile patients are often committed precisely because the family feels that they cannot live together, pressure will be felt by the institution to keep, rather than release, such patients during the period immediately following hospitalization.

Another reason why hospital staffs may not be successful in sorting out patients who do not need to be institutionalized is that institutionalization itself may induce aberrant behavior, thus reinforcing the admitting psychiatrist's original judgment that the patient needs hospitalization. The normal response to the bizarre surroundings and depersonalized atmosphere of such institutions has been aptly termed a process of "mortification."157 Scheff suggests that hospitalized patients are "rewarded for playing the stereotyped deviant role." that every doctor has a vague but firm notion of how a patient ought to behave when ill, and that patients respond to this expectation. ${ }^{159}$ The patient's own mental disorganization may contribute to adoption of the expected deviant role: "It can be argued that when a person is in a confused and suggestible state, when he organizes his feelings and behavior by using the sick role, and when his choice of roles is validated by a physician or others, he is 'hooked' and will proceed on a career of chronic illness."160 Simce the patient is constantly receiving cues fron the expectations of the staff and the behavior of other patients, the product may be behavior which is not readily distinguishable fron 1 other patients.

Day-to-day realities of the manner in which patients and staff interact on a hospital ward may not be conducive to an objective appraisal of the mental state of a patient who is protesting his or her confinement; indeed, strenuous requests for discharge may themselves be viewed as signs of pathology. Dr. Szasz has noted, "The relationship between physicians and patients in psychiatric hospitals is often a struggle between adversaries; this fact requires legal recognition.".61 In the case of juvenile voluntary commitments, the law has not made that recognition.

156. T. SCHEFF, supra note 116 , at 167.

157. E. Goffman, The Moral Career of the Mental Patient, in Asyuums 117-55 (1961).

158. T. SCHeFF, supra note 116 , at 84 .

159. Id. at 84-87.

160. Id. at 121.

161. T. SZASZ, supra note 30 , at 181. 


\section{Labelling}

Even if a child were to be released at an early date, damage may have been done to the child by the experience of hospitalization. Hospitalization is the surest way of attaching the label of "crazy" or "mentally ill" to a person, and such a label carries with it the adverse reaction of other people who find out about the hospitalization in a person's past. The "crazy" label can also have a powerful impact upon the self-concept of the person institutionalized, especially where that person is young and impressionable. Scheff argues that this kind of labelling is the single inost important cause of "careers of residual deviance." The act of labelling reverses the presuinption of normality which is usually accorded a person's actions. Simce the presumption of abnormality attaches to the "former mental patient," the amount of deviance in his or her behavior will be exaggerated in the perceptions of others, and perhaps in fact. ${ }^{162}$ Oddities of behavior which would not be noticed in a "normal" person will be seen as proof of continued craziness in a former mental patient. Craziness will be found in these actions, and the label will be renewed and confirmed. Psychiatric labels, once attached, gain a life of their own, and even when the person no longer exhibits any manifestations of mental disease, his illness is considered to be "in remission." The remission label carries with it the connotation that the person will at some time begin to behave in a crazy inanner again. Thus the discharged patient, his relatives, and his friends gain the expectation that the illness will recur, and this expectation becoines a self-fulfilling prophecy in many cases; ${ }^{163}$ such a label may be a primary cause of the situation which it purports to describe. ${ }^{164}$

\section{E. A Role for the Independent Psychiatrist}

One alternative would be to provide an independent psychiatrist for the child at all commitment proceedings. The independent psychiatrist can avoid the pitfalls discussed above, by functioning as a part of a legal process, and in conjunction with the child's counsel. Thus, while the psychiatrist in a inodel juvenile commitment system would remain vitally important as the source of expert knowledge concerning the child's problems, psychiatric expertise would be only one of several inputs into a judicial determination of the wisdom of the proposed commitment.

162. T. ScHEFF, supra note 116 , at 154 .

163. Rosenhan, supra note 139 , at 253-54.

164. R.D. LAING, supra note 124 , at 41-42. 
V.

\section{The Child: Development of a New Role}

The present "voluntary admissions" system gives parents almost total discretion to commit their children, subject only to the check of the admitting physician. The child's role is limited to influencing, by argument or behavior, the parents and doctor. A central thesis of this Article is that the child's role in commitment proceedings can and should be expanded. One must first accept either as a matter of constitutional law or as an article of secular faith, the idea that children are persons and that as persons they have a right to be heard in matters which significantly affect their lives. These assumptions underlie this Article. Hospitalization-because it deprives children of liberty and because it leaves psychological wounds which in some cases never heal-so vitally affects the lives of children that the law is obligated to solicit and consider their opinions before allowing them to be committed.

\section{A. The Constitutional Framework}

\section{Children, Parents, and the State}

The delineation of children's riglts by the United States Supreme Court is still in nascent condition. Early cases involving children were generally viewed as controversies between parental authority and the authority of the state, the rights of children often receiving only a fleeting reference. In Meyer v. Nebraska, ${ }^{165}$ the Court noted in passing that the liberty guaranteed by the fourteenth amendment includes the right to "acquire useful knowledge." "168 In Pierce v. Society of Sisters, ${ }^{167}$ after noting the contention that the enactment conflicted with "the right of the child to influence the parents' choice of a school,", the Court rested its decision on the interference with the authority of parents and guardians to direct the unbringing and education of their

165. 262 U.S. 390 (1923) (reversing the conviction of a teacher by using the substantive due process doctrine of that era). For a brief abstract of the case, see text accompanying notes 67-68 supra. See discussion of parents' rights accompanying uotes 64111 supra.

166. Id. at 399. This remark probably referred to the rights of the pupils to learn. It could, however, have been meant to buttress the rights of the teacher. It follows a reference to occupational interests, and might be read to highlight the right of a teacher to put acquired knowledge to use in teaching. The Court seems to have accepted the former interpretation. Justice Rutledge wrote in Prince v. Massachusetts, 321 U.S. 158 (1944), that "children's rights to receive teaching in languages other than the nation's coinmon tongue" had been guarded in Meyer. Id. at 166. See also Tinker v. Independent Community School Dist., 393 U.S. 503, 506 (1969) (Meyer said to have protected the liberty of teacher, student, and parents).

167. 268 U.S. 510 (1925). See text accompanying notes 69-70 supra. 
children, and the rights of the private school to engage in business free from unreasonable interference with its patrons. ${ }^{100}$

In West Virginia State Board of Education v. Barnette, ${ }^{170}$ the Court seems to have recognized that children are entitled to first amendment protections. ${ }^{171}$ The plaintiffs won an injunction against the expulsion of children who would not salute the flag, and against prosecution of parents and guardians for aiding in their delinquency. ${ }^{172}$ One year later, in Prince v. Massachusetts, ${ }^{173}$ the Court explicitly distinguished between the claims of parents and children. ${ }^{174}$ In Prince the guardian of a 9-year-old child was convicted of violating state child labor laws by furnishing a child with nnagazines, knowing that the child would sell thein unlawfully, and by permitting a child in her custody to "work" contrary to law. ${ }^{175}$ The guardian and child were Jehovah's Witnesses and had been distributing copies of Watchtower and Consolation, engaging in what they considered to be a rehgious duty. ${ }^{170}$ The Court acknowledged that two claims were at stake: the parent's right to bring up the child, and the child's right to follow the tenets and practices of their faith. ${ }^{177}$

Writing for the Court, Justice Rutledge proceeded to characterize the state's assertion of authority as representing "the interest of society to protect the welfare of children,"178 and analyzed the case by con-

168. Id. at 532 .

169. Id. at 534-36. In Prince v. Massachusetts, 321 U.S. 158 (1944), Justice Rutledge described the Court's action in Pierce as sustaining both "the parent's authority to provide religious with secular schooling, and the child's right to receive it ...." Id. at 166.

170. 319 U.S. 624 (1943).

171. The question which underlies the flag salute controversy is whether a ceremony so touching matters of public opinion and political attitude may be imposed upon the individual by official authority under powers coinmitted to any political organization under our Constitution.

Id. at 636.

Neither our domestic tranquility in peace nor our martial effort in war depend on compelling little children to participate in a ceremony which ends in nothing for them but a fear of spiritual condemnation.

Id. at 644 (Black \& Douglas, JJ., concurring). But cf. Justice Frankfurter's statement in dissent:

And the question here is whether the state may make certain requirements that seem to it desirable or important for the proper education of those future citizens who go to schools inaintained by the states, or whether the pupils in those schools may be relieved from those requirements if they run counter to the consciences of their parents.

Id. at 657 (Frankfurter, J., dissenting).

172. Id. at 629-30, 645 .

173. 321 U.S. 158 (1944).

174. Id. at 164 .

175. Id. at 160 .

176. Id. at 161-63.

177. Id. at 164 .

178. It is the interest of youth itself, and of the whole community, that 
sidering the constitutionality of the child labor law. He asserted that the state's authority over children's activities was broader than over those of adults, ${ }^{179}$ and that the regulation in question was not unreasonable. ${ }^{180}$

In dissent, Justice Murphy accepted the tenet that the power of the state to control the activities of chidlren was broader than its power over adults, ${ }^{181}$ but reached a different result. He beheved that the risk of nonpersuasion was on the state to prove the "reasonableness and necessity" of the prohibition. ${ }^{182}$ Justice Murphy concluded that the state had failed to meet this stricter standard of review. Because a restriction on religious acitivity was involved, Justice Murphy required the state to justify the regulation and employed a more exacting rule of law.

The majority in Ginzberg v. New York, ${ }^{183}$ drew strength from the holding of Prince. In Ginzberg, the Court sustained a state's use of variable concepts of obscenity by which material which would not be obscene for adults was obscene for those under eighteen. ${ }^{184} \mathrm{~A}$ New York statute made unlawful the knowing sale to a person under seventeen of magazines which contain pictures depicting nudity and which are harmful to minors. ${ }^{185}$ In his majority opinion, Justice Brennan explained that the legislature could properly conclude that the law would assist parents and teachers to care for minors. ${ }^{186} \mathrm{He}$ then asserted a distinct societal interest in the well-being of its youth. ${ }^{187}$ In both regards he made reference to Prince. He found that the New York legislature might rationally conclude that exposure to these inate-

children be both safeguarded from abuses and given opportunities for growing into free and independent well-developed men and citizens.

....

Acting to guard the general interest in youth's well being, the state as parens patriae may restrict the parent's control by requiring school attendance, regulating or prohibiting the child's labor, and in many other ways.

Id. at 165-66 (footnotes omitted).

179. Id. at 168 .

180. Justice Rutledge contrasts his analysis with one requiring the showing of a clear and present danger. Id. at 167 . Instead, he accepts the statntory classifications of children and selling activities as appropriate. While he appears to begin a search for justification of the regulation in the particular fact situation of the case, he short circnits the analysis with a generalized assertion of "harmful possibilities" and eventually defers to the state's determination that an absolute prohibition is necessary to accomplish its objectives. Id. at 169-70.

181. Id. at 173.

182. Id.

183. 390 U.S. 629 (1968).

184. Id. at 638 .

185. Id. at 633 .

186. Id. at 639.

187. Id, at 640 . 
rials would be harmful to young people. ${ }^{188}$

In Tinker $v$. Des Moines Independent Community School District, ${ }^{189}$ the conflict was again one between state regulation and children's rights. The majority opinion of Justice Fortas left no doubt that the children were exercising their first amendment rights of expression by wearing black armbands to school in protest against the hostilities in Southeast Asia. ${ }^{190}$ The Court recognized students as "persons under our Constitution," and failed to discount their complement of rights. ${ }^{101}$ While Tinker reaffirmed children's right to first amendment protection vis a vis the state, it did so in a setting of family solidarity; the protesting students and their parents were in agreeinent. ${ }^{192}$

It was not until Wisconsin v. Yoder, ${ }^{103}$ that the prospect of children asserting first amendment rights in opposition to their parents' wishes was raised, and even then, most vigorously in the dissenting opinion of Justice Douglas. ${ }^{194}$ Justice Douglas was quick to point out that the compulsory education requirement in issue effected not only the free exercise claims of Amish parents, but also those of their high school children. ${ }^{105}$

If the parents in this case are allowed a religious exemption, the inevitable effect is to impose the parents' notions of religious duty upon their children. Where the child is mature enough to express potentially conflicting desires, it would be an invasion of the child's rights to permit such an imposition without canvassing his views. ${ }^{100}$

188. Id. at 641-43. Since no argument was advanced that the magazines were not harmful to minors, Justice Brennan recognized no issue concerning the obscenity of the material. Id. at 635. Since obscenity is not "protected speech," Justice Brennan felt justified in using this permissive rule of law. Id. at 641.

189. 393 U.S. 503 (1969).

190. Id. at 507,508 .

191. Id. at 511 .

But see the concurring opinion of Justice Stewart. Justice Stewart refers to both Prince and Ginzberg, and quotes from his concurring opinion in Ginzberg:

A State may permissibly deternine that, at least in some precisely determined areas, a child-like someone in a captive audience-is not possessed of that full capacity for individual choice which is the presupposition of First Amendinent guarantees.

Id. at 515, quoting from 390 U.S. $629,649-50$ (1968).

192. 393 U.S. at 504. Cf. id. at 516.

193. 406 U.S. 205 (1972).

194. Id. at 241-46. See also id. at 237 (Stewart, J., concurring); id. at 238

(White, J., concurring); id. at 230-32 (Burger, C.J., dictum).

195. Id. at 241 .

196. Id. at 242 .

One line of argument drawing strength from the first amendment cases of Tinker and Barnette is that a child-like other persons-has a right to the integrity of his or her own personahity, and that until it can be shown that aberrant behavior is a pathological danger to the safety or peace of others and not merely a harmless expression of individual style, parents have no right to coerce changes in that behavior. The no- 
Justice White accepted the possibility that some Amish children might abandon the Amish faith and way. ${ }^{197}$ He recognized:

A State has a legitimate interest not only in seeking to develop the latent talents of its children but also in seeking to prepare them for the life style that they may later choose, or at least to provide thein with an option other than the life they have led in the past. ${ }^{198}$

But in the circumstances of this case, ${ }^{199}$ he decided the close question by concurring with the majority. Justice Stewart was more vehement and read the record as not presenting a question of conflicting free exercise claims. ${ }^{200}$

Chief Justice Burger, writing for the majority, held that the state could not compel these respondents to make their children attend formal high schools until age sixteen. ${ }^{201}$ He noted that it was the parents who were subject to prosecution, and that the holding "in no degree depend[ed] on the assertion of the religious interest of the child as contrasted with that of the parents." ${ }^{202}$ Chief Justice Burger did proceed to intimate the view that recognition of a claim by the state on the theory that parents were preventing their minor children from attending high school contrary to the children's wishes would have brought into question traditional concepts of parental control over the upbringing and education of their children. ${ }^{203}$

These cases suggest several lessons. (1) Children are persons and enjoy constitutional rights and protections. ${ }^{204}$ (2) The children's interests have generally been seen as allied with those of their parents. ${ }^{205}$ (3) In conflicts between the interests of parents and children, the rights of children and the role of the state are still without

tion of a danger sufficient to justify the limitation of a child's expression of personality is an adaptation of the first amendment rule of law commonly called clear and present danger. Application of this exacting standard of justification goes beyond the intensity with which the courts have generally been willing to review disputes between parents and children.

197. Id. at 240.

198. Id.

199. Here the children did attend public schools through the eighth grade, and there was no evidence that Amish children who did decide to leave would not be able to acquire additional academic training and skills. Id. at 238,240 .

200. Id. at 237 .

201. Id. at 234 .

202. Id. at 230 .

203. Id. at 230-34.

204. Tinker v. Independent Community School Dist., 393 U.S. 503 (1969); Bd. of Educ. v. Barnette, 319 U.S. 624 (1943).

205. See Wisconsin v. Yoder, 406 U.S. 205 (1972); Timker v. Independent Con1munity School Dist., 393 U.S. 503 (1969). Cf. Bd. of Educ. v. Barnette, 319 U.S. 624 (1943); Pierce v. Society of Sisters, 268 U.S. 510 (1925); Meyer v. Nebraska, 262 U.S. 390 (1923). But see text accompanying notes 195-96 supra. 
clear delineation. ${ }^{208}$ (4) The state may act to limit parents' discretion with regard to their child.207 When it does, its interest are twofold: a) protecting the imterests of the child, and b) furthering a general societal interest in the well-being of its youth.

\section{The Child and Procedural Due Process}

The Court has been vigorous in extending to children the procedural safeguards provided in the Bill of Right for those accused of crimes. Between 1966 and 1971, almost all the procedural safeguards of adult defendants were extended to children in delinquency proceedings. In Kent $v$. United States, ${ }^{208}$ limits were placed upon the power of juvenile courts to waive jursidiction, thereby sending the accused child to trial as an adult. The parental function of the juvenile court judge, Justice Fortas noted, is "not an invitation to procedural arbitrariness." 209 In re Gault ${ }^{210}$ reinforced Fortas's warning by holding that due process required notice of the charges, right to counsel, right to confrontation and cross-examination of witnesses, and the privilege against self-incrimination in juvenile proceedings. In re Winship ${ }^{211}$ added to the hist of protections by holding that due process in juvenile delinquency cases required proof beyond a reasonable doubt. ${ }^{212}$

With rare exception, ${ }^{213}$ the Court has held that children may not be demied the procedural protections afforded adults. In so doing, it has rejected "the assertion that a child, unlike an adult has a right "not to liberty but to custody." "214 Instead, the holdings of these cases are consistent with an analysis which begins by assuming children are entitled to full constitutional rights, and which proceeds to limit these rights only when accommodation is required to resolve a conflict with the interests of parents, society, or what appears to be the child's best interest. ${ }^{215}$

206. Wisconsin v. Yoder, 406 U.S. 205 (1972). The next sections of this Comment will examine these questions and suggest a resolution of this problem im the setting of the voluntary commitment of children by their parents.

207. Prince v. Massachusetts, 321 U.S. 158 (1944). Cf. Ginzberg v. New York, 390 U.S. 629 (1968).

208. 383 U.S. 541 (1966).

209. Id. at 555 .

210. 387 U.S. 1 (1967).

211. 397 U.S. 358 (1970).

212. Id. at 368.

213. The Court failed to make this process complete when a plurality later held that due process did not require trial by jury in juvenile courts, because of the allegedly damaging effects on juvenile offenders and the functioning of juvenile courts. McKeiver v. Pennsylvania, 403 U.S. 528 (1971).

214. In re Gault, 387 U.S. 1, 17 (1967).

215. In one case, the Court used differences between children and adults as one reason for extending the privilege against self-incrimination to juveniles: "[A]uthorita- 


\section{B. An Expanded Role for the Child}

\section{Judicial Review of Parens Patriae and Patria Potestas}

The configuration of interests in juvenile commitment proceedings is a closed triangle; any expansion of the child's rights must be accommodated on another side. The Count has been noticeably more reticent in checking parental discretion than in limiting the power of the state..$^{216}$ One obvious reason why the courts have been willing to maintain children's rights against the state but not against their parents is that parents could be expected to shake the political foundations over such rulings, whereas the state's interests are more abstract and less likely to be expressed politically.

A second factor may be that in some situations under review, the state's position vis a vis both parents and children has been weakened by the conflicting dictates of the parens patriae doctrine. The two relevant elements of this doctrine are (1) that the state in its role as protector of the weak must sometimes protect children froin their parents, and (2) that in certain circumstances the state may require both parents and children to act in such a way as to promote the societal interest. These two elements are in conflict where the aggressor against the child is the state, itself. In this regard, the Gault and Tinker decisions may be read to require a preference for the protectionist role of the state over the activist role. ${ }^{217}$

The voluntary commitment of children by their parents seems closer to a traditional parens patriae situation in which the emphasis is on protection. The axis of potential conflict is between children and their parents. The parents initiate the commitment process by volunteering their child. The state's power has up until now been exercised or reserved in support of that parental choice. Instead, the state could provide more effective safeguards so that the interests the child perceives as his or her own will not go unrecognized in so vitally iniportant a matter.

It may not be necessary to mount a direct attack against parental control. While the courts inight be uneasy about restricting parental prerogatives, they may not be indifferent to the argument that the state, in denyimg procedural safeguards to juveniles, now enforces blanket discrimination against children. Under the current system, the

tive opinion has cast formidable doubt upon the reliability and trustworthiness of 'confessions' by children." In re Gault, 387 U.S. 1, 52 (1967). See also Haley v. Ohio, 332 U.S. 596 (1948).

216. See discussion accompanying notes 193-207 and notes 208-215 supra.

217. Kleinfeld, The Balance of Power Among Infants, Their Parents and the State, pt. III, The Relation to The State, 5 FAM. L.Q. 64, 107 (1971) [hereinafter cited as Kleinfield III]. 
state automatically endorses the parents' view of the child's problems. The state, through the courts, should instead take a more even-handed approach and weigh the preferences and interests of both parents and child before determining whether commitment is necessary. ${ }^{218}$

\section{Conceptions of Age and Responsibility}

Legal perceptions of age and responsibility may be critical to any attempt to change the present system of juvenile commitment. ${ }^{210}$ The setting of age limits for the enjoyment of legal rights seems peculiarly a legislative function. Arguments about how old children must be before they can participate in their own commitment proceedings may ultimately lave to be decided by state legislatures. The age limit currently in force for most purposes in most states is 21 .

Suggestions for varying that limit with regard to some circumstances have been advanced. One proposal for the particular setting under discussion was made in the National Institute of Mental Health's Draft Act Governing Hospitalization of the Mentally Ill. It suggested that 16 is the age at which persons should be able to seek voluntary' hospitalization on their own initiative, or, once hospitalized, seek their own release. ${ }^{220}$ The Act's Commentary argues for the lower age on the basis of such factors as the legal capacity of adolescents to consent to surgery, ${ }^{221}$ and their legal responsibility for criminal acts-a matter which varies from state to state. These arguments have not proven totally persuasive; some states which have adopted the Draft Act have modified it to make the age of responsibility $21 .{ }^{222}$

Citing the works of Piaget and other authority, Justice Douglas argued for an even younger age of responsibility in his Yoder dissent. $^{223}$ Noting that 14- and 15-year-olds are often permitted to

218. Judges may be more receptive to arguments emphasizing the law's developing guarantees of children's rights than to allegations of irrationality or vindictiveness on the part of parents seeking to commit their children. The role of the state is the preferred ground upon which to argue. It will be incumbent upon the children's rights advocates to demonstrate that the state's failure to give children any voice in the matter of their own commitment is unreasonable. By asserting rights of expression and due process, petitioners will be seeking a strict standard of judicial review. By eharacterizing the conflict along children-state lines, they will strengthen the possibility of evoking a favorable rule of law.

219. Even if children's rights advocates succeed with arguments similar to those advanced here, some differentiation among children on the basis of capacity or age may still be essential. What is left to parental discretion when an infant is six inonths old may no longer seem so compelling when the child becomes a tcenager.

220. Draft Act (Commentary), supra note 17, at 19-20.

221. An assumption which appears to be erroneous, see text accompanying notes 81-84 supra.

222. Ross, Hospitalization of the Voluntary Mental Patient, $53 \mathrm{MICH}$, L. REv. 353, 360 (1955).

223. Justice Douglas cites: 
testify in custody proceedings, Douglas argued that the moral and intellectual maturity of children at age 14 is close to that of an adult. ${ }^{224}$

As Justice Douglas noted, an important area of judicial decisions allowing choices to children is that of custody cases. It has been vigorously argued that the child's interest should be separately presented to the court in custody cases, and that neither parent's attorney can present the child's position in an objective form, although both will argue that it is in the child's best interest that their client have custody. ${ }^{225}$ It has been observed that the child's right to be heard in custody decisions derives from the "notion that a youth has certain inherent rights to free association, extending to the custodial relationships to which he is subject," ${ }^{226}$ and also draws strength from analogy to the rules of civil procedure dealing with compulsory joinder of parties and intervention by right. ${ }^{227}$

Either by statute or judicial decision, many states recognize that the choice of a child of a certain age, usually between 10 and 14 , should be considered as a factor in awarding custody. ${ }^{228}$ This choice will only be honored if the parent chosen by the child meets the court's standards of "fitness," and even then, in most jurisdictions, the child's preference is treated "as simply another relevant factor."229 The Uniform Marriage and Divorce Act directs the judge to "give due weight to the wishes of the child if he is of sufficient age and is capable of forming an intelligent preference," and to follow the preferences of a child of 16 or over, unless "the child is so mentally or emotionally disturbed as to be unable to form an intelligent preference;"230 but the drafting committee of the National Conference of Commissioners

J. Piaget, The Moral Judgment of the Child (1948); D. Elkind, Children and Adolescents 75-80 (1970); Kohlberg, Moral Edncation in the Schools: A Development View, in R. Mnuss, Adolescent Behavior and Society 193, 199200 (1971); W. Kay, Moral Development 172-183 (1968); A. Gesell \& F. Ilg, Yonth: The Years from Ten to Sixteen 175-182 (1956).

406 U.S. 205, 245 n.3 (Douglas, J., dissenting).

224. Id.

225. Inker \& Perratta, A Child's Right to Counsel in Custody Cases, 55 Mass. L.Q. 229, 235 (1970). See also CHILDREN IN THE CoURTS-THE QUESTION OF REPRESENTATION 21-143 (G. Newman ed. 1967).

226. Kleinfeld II, supra note 77 , at 442 .

227. FED. R. Crv. P. 19(a), 24(a)(2), cited in Kleinfeld, The Balance of Power Among Infants, Their Parents and the State, pt. I, The Representational Context, 4 FAM. L.Q. 320, 324-26 (1970) [hereinafter cited as Kleinfield I].

228. Annot., 4 A.L.R.3d 1396 (1965).

229. C. Foote, R. Levy \& F. Sander, Cases and Materials on Family LaW 852 (1966). For some other factors which may be considered, see, e.g., Painter v. Bannister, 258 Iowa 1390, 140 N.W.2d 152, cert. denied, 385 U.S. 949 (1966).

230. Uniform Marriage and Divorce Act, Section 4.9 (First Tentative Draft, Second Working Draft 1969). 
on Uniform State Laws rejected this proposal as too far-reaching. ${ }^{231}$

State laws tend to give more weight to a child's choice where the child is not choosing between parents in a divorce. Courts are less eager to grant the child's wishes where such a choice may disrupt the relationships within an existing family. The situation of a minor protesting against hospitalization sought by his or her parents is closely analogous to custody choice during divorce; the family still exists but has been broken by the parents' desire to have the child removed to an institution. In a custody decision following divorce, the judge considers the child's preferences and objections along with other evidence from other family members. The proposed expanded role of the child in voluntary commitment proceedings would likewise have the judge consider the child's point of view along with other evidence before determining whether the child should be committed. Some commentators contend that adult choices can be entrusted to children from about the age of 13 on asserting:

"[P]ersons generally reach their adult levels of abstract intelligence and moral development long before the termination of infancy, at around puberty. For about the last eight years or so of infancy, a person has about as much capacity to exercise choice as an adult, yet is demied adult liberty." 232

One interesting suggestion is that of Ennis and Siegel, who argue that "anyone who is old enough to protest his hospitalization should have the right to a court hearing to oppose hospitalization, whether his parents want him to have a hearing or not." ${ }^{233}$ This proposal might make unnecessary the setting of an arbitrary age limit. ${ }^{234}$

In considering the proper extent of a child's participation in commitunent proceedings, it should be borne in mind that the choices and the responsibility required are not limitless. Even adults who seek to contest their own commitment or who atteinpt to terminate their hospitalization are not given total discretion under the law. It is assumed that mental illness may mipair their capacity to make this choice; thus

231. C. Foote, R. Levy \& F. Sander, Cases and Materials on Family Law 14849 (Supp. 1971).

232. Kleinfeld III, supra note 217, at 69 (footnote omitted).

233. B. ENNIS \& L. SiEger, supra note 35, at 38-39.

234. Courts still may shy away from state action in sitnations where the controversy is between a parent and child. For example, in Kentera v. Boesel, $41 \mathrm{Cal}$. $2 \mathrm{~d}$ 639,262 P.2d 317 (1953), a California court refused to honor the request of at 14year-old boy that his grandmother be appointed his guardian. The boy was living with his divorced mother and the court did not consider the appointment "necessary or convenient." Id. at $644-45,262$ P.2d at 320 . The court explaimed that the statutory provisions allowing minors over the age of 14 the privilege of nominating their guardians "were not intended to upset the normal relationship of parent and child or to disrupt normal family discipline by allowing the 14-year-old minor to withdraw from the family circle at his whim." Id. at 643, 262 P.2d at 319. 
judicial review is provided as a check on their possibly ill-advised choice. This check, in the form of a hearing before a judge, could also protect against the possibly unwise objections of an adolescent.

Evaluating the proper role of the child in a new legal framework for juvenile commitment decisions is difficult, partly because so little legal thinking has been done regarding the law's relationship to children. ${ }^{235}$ It should be clear that there is little justification for the present practice of giving the child no role at all. It is equally clear that for children's rights to inean anything, access to effective counsel inust be provided at each stage at which the child's substantive rights are at issue. But it is important in devising a new systein of juvenile coinmitment procedures not to allow the wishes and plight of the child to get lost in the coinpeting interests and efforts of his or her parents, psychiatrist, and counsel. If the provision of counsel and a forum in which to be heard merely bureaucratizes an assembly line process in which children are automatically committed to hospitals, then the legal process will be camouflaging a sham, and the wishes of the child will remain an irrelevancy. Thus, the counsel and forun provided must be truly effective.

\section{VI}

\section{The Lawyer: Provining Effective Counsel}

Any attempt to reduce the power of parents and psychiatrists by giving a voice to children whose hosptialization is being sought will necessarily depend on an entarged role for counsel so that the children may exercise their rights effectively.

Presently, lawyers play a neghigible role in the juvenile commitment process. In some cases attorneys may be useful in negotiating a juvenile's release from a hospital, ${ }^{230}$ but this is a relatively rare occurence because, as a practical matter, few young patients have access to counsel. The lawyer, if somehow retained, has little leverage simce in most jurisdictions legal remedies are simply not available to juvenile clients. "Only in jurisdictions requiring judicial or other independent hearings is counsel actually accorded an opportunity to function properly. Without the learing, the counsel is like an actor without a stage." ${ }^{237}$ In order to understand the function counsel might perform in a new system of juvenile commitments, it may be useful

235. Exceptions are the areas of estates, probate law, and juvenile delinquency. Kleinfeld, The Balance of Power Among Infants, their Parents and the State, 4 FAM. L.Q. 320 (1970).

236. See, e.g. Oran, supra note 151 , at 20.

237. N. KrrTRIE, supra note 4, at 92. 
to examine the role of lawyers in related areas: the adult commitment process and juvenile courts.

\section{A. The Representation of Adult Mental Patients}

\section{The Role of Counsel}

Even in adult commitment proceedings, the status of counsel varies widely froin state to state. Forty-one states and the District of Columbia provide for the appearance of counsel at commitment hearings, but appointment is inandatory in only about half of those jurisdictions. ${ }^{238}$ In almost every state where lawyers have been provided, the right is based upon legislative policy rather than a juducial holding that counsel is required by the Constitution. ${ }^{230}$ Thus, there has been no blanket extension of the right to counsel to prospective mental patients in the manner that In re Gault extended the right to juvenile delinquents and Argersinger $v$. Hamlin ${ }^{240}$ extended it to nonfelony defendants subject to imprisonment. With regard to this gap in Supreme Court decisions, Professor Kittrie argues that mental patients have a greater need for an attorney's assistance than criminal defendants because they are subject to "even more far-reaching interference with their property rights," and inore importantly because "they are less likely than felons to comprehend the nature of the proceedings and their consequences or to be able to represent their own interests." 241

Inadequate legislation and a lack of favorable judicial decisions are not the only reasons that mental patients received representation inferior to that afforded criminal defendants. The attitudes and practices of the bar may reduce the value of counsel to a patient fortunate enough to have a lawyer. One of the major reasons for poor representation of inental patients is the heavy caseload of public defenders $^{242}$ and appointed counsel ${ }^{243}$ in many jurisdictions. Appointed at-

238. Cohen, supra note 29 , at 437.

239. Id. For examples of cases holding that there is a constitutional requirement of appointed counsel for indigent patients see In re Barnard, 455 F.2d 1370 (D.C. Cir. 1971); Heryford v. Parker, 396 F.2d 393 (10th Cir. 1968); Dixon v. Attorney General, 325 F. Supp. 966 (M.D. Pa. 1971); People ex rel. Rodgers v. Stanley, 17 N.Y.2d 256, 217 N.E.2d 636, 270 N.Y.S.2d 573 (1966). A summary of the constitutional arguments can be found in Andalman \& Chambers, Effective Counsel for Persons Facing Civil Commitment: A Survey, a Polemic, and a Proposal, 45 Miss. L.J. 43, 44-46 (1974).

240. 407 U.S. 25 (1972).

241. N. KITTRIE, supra note 4, at 91.

242. Prior to the adoption of the Lanterman-Petris-Short Act, CaL. WeLf. AND INSTN's CODE $\$ \S 5000-5401$ (Wcst 1972), in 1967, one California public defender testified that he handled 45 to 50 commitment cases per week, and that he produced witnesses in five percent of those cases or less. Testimony of Phillip Smith, California Assembly Interim Comm. on Ways and Means, Subcomm. on Mental Health, Public Hearings, Los Angeles, December 20, 1965.

243. Cohen describes one appointed attorney in Travis County, Texas, who was 
torneys typically have little time to prepare a defense, or even to interview the client prior to the hearing. 244

Even retained attorneys do not always provide the most vigorous defense for their clients in civil commitment cases, either for lack of expertise in the mental health area ${ }^{245}$ or for lack of remuneration. ${ }^{246}$ The lack of an adversary setting even for adult commitment proceedings in many jurisdictions ${ }^{247}$ may nake attorneys uncertain about their proper role. ${ }^{248}$ Occasionally an attorney may feel that the client would profit from hospitalization, ${ }^{249}$ or even fear that as the attorney, he or she may be seen as responsible for violent or self-destructive acts the client might commit if released into the community. ${ }^{250}$

\section{Criticism of the Attorney}

There are different appraisals of the potential effect of increasing the lawyers' role in juvenile commitment proceedings. In response to a recent article calling for greater legal safeguards for those confronted with involuntary hospitalization, ${ }^{251}$ one reader who agreed with the indictment of the commitment process argued that the entry of lawyers into the cast confronting the patient could only make things worse and would be "akin to suggesting that a Jewish Preservation

assigned forty cases, all to be heard in one day. The attorney did not interview any of his clients prior to the hearings, and the only real functions he performed were to see that statutory notice requirements had been met and to sign the jury waiver form. Cohen, supra note 29 , at $428-30$.

244. Id. At least one court has held that failure of the attorney to interview his or her client does not constitute a denial of due process, since the appointment of counsel is sufficient to create a presumption of regularity. Prochaska v. Brimegar, 251 Iowa 834,102 N.W.2d 870 (1960).

245. Bruce J. Ennis, staff attorney for the New York Civil Liberties Union and the Mental Health Law Project, argues that:

[W] hile appointment of an inexperienced attorney to represent a mental patient may confer the aura of fairness, the attorney rarely provides the patient with adequate or effective representation. Widespread reform will not come until there is au available body of lawyers with specialized training in this area.

Ennis, Mental Illness, 1969-70 Annual Survey of American Law 29 (1970).

246. Cohen, supra note 29, at 450; Wexler, Administration of Psychiatric Justice:

Theory and Practice in Arizona, 13 ARIz. L. REv. 1, 52 (1971).

247. Colien, supra note 29 , at 424 .

248. See Andalman \& Chambers, supra note 239 , at $46-54$.

249. Wexler, supra note 246 , at 53.

250. Similar feelings have been attributed to judges:

Little acclaim will come to him for teu aggressive patients successfully treated in the community and little condemnation for ten harmless patients needlessly confined, but condemnatiou (and guilt) may hound him for one ill person released to the community who commits a serious assault.

Chambers, Alternatives to Civil Commitment of the Mentally Ill: Practical Guides and

Constitutional Imperatives, 70 MrcH. L. REv. 1107, 1123 (1972).

251. Oran, supra note 151. 
Society would best be served by the Nazis." ${ }^{252}$ Another reader suggested that increased legal checks against psychiatric overdiagnosis would lead to a cautious underdiagnosis which would leave many sick people without treatment:

Who will these people and their relatives point to when adequate treatment is not provided? The lawyers who established the legal standards? No, the psychiatrists, physicians and hospital personnel expected to provide treatment. When legal action is taken, who will represent them? You guessed it, the lawyers who established the standards. ${ }^{253}$

A policemen responded to the article with the arguinent that persons who cannot be involuntarily committed may face imprisonment for their dangerous acts, and thus would be worse off. ${ }^{254}$ These reactions suggest a general skepticism among the public to legal representation of inental patients.

Resistance to legal procedures is not confined to cases in which the prospective patient is released into the community. Some critics argue that when the attempt to commit a person is successful, the necessity of going through a complicated legal proceeding will prove detrimental to the patient's inedical interests. ${ }^{255}$ In the case of a paranoid patient, it is argued that "the experience of being confronted with forensic argument invariably tends to aggravate his illness rather than prepare him for acceptance of hospital care"250 by "arousing a feeling of public shame, creating a condition of maximum excitement and confusion and ... feeding his persecution delusion with objective evidence a therapist would be hard put to rebut."257 Psychiatrists and many lawyers have supported the argunent that soine common procedural safeguards are countertherapeutic for the prospective patient. The procedure most strongly criticized has been the right to a jury which, it is contended, would introduce the kind of argumentation and cross-examination found in crininal trials, ${ }^{258}$ thereby traumatizing the

252. Letter from George Keifer to the editor, 7 Psychology TodAY 145 (Dec. 1973).

253. Letter from Robert W. Taylor, Ph.D., to the editor, 7 Psychology ToDAY 145 (Dec. 1973).

254. Letter from Sgt. M.A. Dunlavey to the editor, 7 Psycholooy Todsy 145 (Dec. 1973).

255. Kadish, supra note 12, at 96.

256. Yale Comment, supra note 7, at 1192.

257. Kadish, supra note 12, at 96.

258. A California prosecutor has argued that district attorneys would be forced to push the prospective patient to the breaking point with tough questioning in order to prove the patient's craziness-conjuring up visions of Captain Queeg's court martial in the Caine Mutiny. Testimony of Jess Cannon, Cal. State Senate Judiciary Subconn. on Commitment Procedures for the Mentally Ill, Public Hearings, at 97 (Los Angeles, Feb. 13 and 14, 1964). 
patient and humiliating the patient's family. ${ }^{259}$

It is interesting to note that while the presence of lawyers in the commitment process is widely viewed as countertherapeutic, judges are not viewed in the same way. The presence of a black-robed arbiter, it is often argued, may well convince the patient that justice has been done. ${ }^{200}$ One distinguished jurist, who felt that there was little room for a lawyer's skills in commitment proceedings and who doubted his own technical ability to handle such cases, argued strongly that a judge was better able to reassure a prospective patient that his or her interests were being served than a medical board. ${ }^{261}$ It can be argued, however, that allowing the prospective patient the full protection of due process would be even more therapeutic. One observer has noted that according the patient full legal rights may be "less traumatic than a mere pro forma proceeding which seeks to cut corners on traditional legal paraphernalia."262 It has also been found that democratic procedures can be a useful therapeutic tool in the setting of a psychiatric hospital. ${ }^{263}$ The elements of fairness and participation that are basic to procedural due process may well have the same effect. With respect to juvenile courts the Supreme Court has noted that informal procedures which lack due process protections can adversely affect treatment and rehabilitation. ${ }^{264}$ In civil commitment hearings, therefore, the skills of both judges and lawyers may be needed to provide not just the appearance but the reality of fairness.

\section{B. The Representation of Juveniles in Other Cases}

Representing children has not been a common function of attorneys in our legal system. A 1964 study concluded that "[t] $]$ he juvenile court in the United States has been a court with which the practicing lawyer has had little or no contact." ${ }^{265}$ Admittedly the Gault decision has changed that situation somewhat. Nevertheless, except

259. Id. at 97. It has been shown that courtroom experiences can be made less traumatic for the family of a mentally retarded child if the appropriate social agencies properly prepare the parents for the experience, Kay, Farnham, Karren, Knakal \& Diamond, Legal Planning for the Mentally Retarded: The California Experience, 60 CALIF. L. REv. 438, 481 (1972).

260. Testimony of Judge Allen Miller, Cal. State Senate Judiciary Subcomm. on Commitment Procedures for the Mcntally IIl, Public Hearings, at 135 (Los Angeles, Feb. 13 and 14, 1964); testimony of Judge William A. Munnell, id. at 219.

261. B. Boten, TRIAL JUdGE 266, 269 (1952).

262. Wexler, supra note 246 , at 76.

263. R. Rubenstein \& H. Lasswell, The Sharing of Power in a Psychitric Hospital (1966).

264. In re Gault, 387 U.S. 1, 26 (1967).

265. Skoler \& Tenney, Attorney Representation in Juvenile Court, 4 J. FaM. L. 77 (1964). 
for probate inatters and tort suits which involve insurance company lawyers, in most areas of the law-including commitment to mental institutions-children have not received adequate representation. ${ }^{\text {nns }}$ The reason for this is perhaps more closely related to economics than to any legal doctrine. Generally children do not have independent incomes with which to pay lawyers to represent their interests. ${ }^{207}$ This factor is particularly important where the child's rights are in direct conflict with the interests of the parents.

But economics is not the sole answer to inadequate representation of children. Both children and lawyers need to learn how the lawyer may serve the child's interests. ${ }^{208}$ Since children have often lacked not only the financial resources but also the legal standing ${ }^{2 \mathrm{t}}$ to retain counsel, lawyers are often confused about their own role in representing juveniles. ${ }^{270}$ Defining the lawyer's role inay be very difficult when the child involved is an infant, but should be casier when the child is old enough to verbalize feelings about proposed institutionalization.

\section{The Representation of Juvenile Mental Patients}

The inajor problem facing lawyers who represent juvenile mental patients is that the children involved have no recogmized rights to enforce. They should be accorded rights coinparable to persons in similar situations. Statutes can be drafted which will codify their rights without denying the benefits of treatment to those children who need it. But the enforcennent of these rights will depend on the right to counsel.

\section{Providing Counsel for Juvenile Patients}

Perhaps the hardest question in this entire area is: Which children are to be given the assistance of counsel? Since virtually none

266. Kleinfeld I, supra note 227, 4 FAM. L.Q. at 340-41.

267. Id.

268. Kleinfeld I, supra note 227, at 341.

269. E.g., in California a minor may not participate in litigation as either plaintiff or defendant without the appointment of a guardian ad litem or a guardian of his estate. Cal. Crv. Code $\$ 42$ (West 1954); CaL. Code of Crv. Pro. $\$ 372$ (West 1973). Nor may the child retain a lawyer. Johnstou v. So. Pacific Co., 150 Cal. 535, 89 P. 348 (1907).

270. The legal profession has too often been misled into assuming that its task is simply that of accepting and effectuating plans for children made by parents acting alone or in cousultation with other professionals.

Kay, Farnham, Karren, Knakel \& Dianond, supra note 259, at 528. See, Inker \& Perratta, $A$ Child's Right to Counsel in Custody Cases, 55 Mass. L.Q. 229, 286 (1970). See also J. Goldstein, A. Freud \& A. Solmit, Beyond the Best Interests of the CHIID 65-67 (1973). 
of the minors involved will have imdependent income, some form of public defender system or program of appointed counsel will be necessary. Should all children whose parents seek to have thein institutionalized automatically be given a lawyer? Should the lawyer be provided only when the child requests the assistance of counsel? Should attorneys be provided in every case in which the child expresses a desire to contest the commitment? Should counsel be provided in every case unless the child expressly waives his or her right to be represented?

There is no way of ascertaining whether a child facing commitment needs a lawyer without knowing whether the child really wants to contest the commitment. And since the parents, their psychiatrist and lawyer, cannot be entrusted with the responsibility of determining whether the child is opposed to hospitalization, an independent party must make that determination.

Should the child be able to waive the right to counsel? It is suggested that since one of the key issues in a commitment case is whether the proposed patient is capable of making responsible decisions about his or her life, it is irrational to assume at the outset that the person is capable of deciding to forego representation by an attorney. ${ }^{271}$ Following this reasoning, one court has held that acceptance of the patient's request to discharge counsel will invalidate the resultimg commitment order. ${ }^{272}$ The California Supreme Court has taken this concept one step further in the situation of a patient already hospitalized and held that a request for release triggers the right to counsel where the patient has not consented to treatment. ${ }^{273}$

In the case of juvenile commitments the argument against allowing waiver of counsel is even stronger, since the child may be even less likely to assert a position about his or her own welfare when the child's parents strongly oppose any action by the child to contest the commitment. ${ }^{274}$ And jurisdictions which find a waiver of right to counsel in the fact that a patient has not requested appointment of an attorney wonld effectively limit that right. Courts have recognized that a waiver of rights by a child is impermissible in soine situations in which an adult would be allowed to waive those rights, ${ }^{275}$ and that the confessions of juveniles made without consultation with counsel are

271. Cohen, supra note 29, at 448 .

272. Dooling v. Overholser, 243 F.2d 825 (D.C. Cir. 1957).

273. Thorn v. Superior Court, 1 Cal. 3d 666, 464 P.2d 56, 83 Cal. Rptr. 600 (1970).

274. Kleinfeld I, supra note 227, at 345 .

275. Dixon v. United States, 197 F. Supp. 798, 803 (W.D. S.C. 1961); State ex rel. Byrnes v. Goldman, 59 Misc. 2d 570, 302 N.Y.S.2d 926 (Sup. Ct. 1969). 
particularly suspect. ${ }^{276}$ The same common-sense understanding which required those results is controlling here.

\section{Services Which the Lawyer Can Provide for the Child-Client}

In the system of juvenile commitments proposed in this Article, the most important function of the lawyer would be to ascertain what the real wishes of the client are regarding the proposed hospitalization, and then to advocate the client's position. Eliciting the chient's preferences may require a more sophisticated approach in this kind of case than is required in, for example, the typical corporate taxation case. But the processes are basically parallel. The attorney must first explain to the client what it is that the parents are seeking and how this will affect him or her. The child inust be informed of the nature of the treatment to be received, the restrictions which would be placed on the child during hospitalization, the possible outcomes should the child desire to contest commitment, and the remedies available should the child wish to scek future release.

The nature of the hospital's restrictions will be particularly important for the child to understand. Is it a locked ward? How easy is it to transfer to an unlocked ward? How limited are phone privileges? Are visits by parents possible? Are they required? Is it possible to have friends visit at the hospital? Must they be screened by the hospital staff? Is mail censored? Is it a sex-segregated ward? What limitations are placed on relationships between patients? How does one get permission to leave the grounds? Must one be accompanied on such trips? What kind of activities are available? What kind of activities are required? What kind of punishments are imposed for breaking hospital rules? Who decides on the imposition of punishments? Is medication likely to be required, and if so, what kind? How long is the hospitalization being recommended by the staff, or how long is the average stay in this kind of ward? Will school be required, and if so what kind? What kind of items are contraband on the ward (matches, razors, televisions, hair dryers, drugs, liquor, pornography)? These are the questions that an adolescent client may be most interested in and may be most likely to ask the lawyer. The lawyer may find the answers by asking both hospital staff and patients.

There are other important factors which should be discussed with the client as early as possible. The child should be counselled regarding possible adverse consequences of hospitalization which he or she may face on release. These may include not only probleins related to social stigma, but more important, the likelihood that knowledge

276. In re Gault, 387 U.S. 1 (1967); Haley v. Ohio, 332 U.S. 596 (1948). 
of a prior commitment may prevent the client from getting the kind of education or job he or she may want in the future. This involves not just the nature of possible discrimination against the client as an ex-mental-patient, but also the question of how likely it is that prospective employers or schools will find out about the hospitalization. The lawyer should also discuss the likelihood of successfully challenging the proposed commitment, and the alternatives if hospitalization is avoided. This is particularly important if the family situation is such that it is not possible or desirable for the child to return home.

While giving the client this information, the lawyer should also be seeking to find out how the client perceives his or her own condition and family situation. The lawyer will want to determine what the clients think about their need for treatment; low they relate to various forms of treatinent; how they feel about living at home; and how they evaluate the parents' request for hospitalization. It will be important to elicit the client's true feelings, even if they are ambivalent. An imitial response of "Whatever they want for me must be best" or "They've been trying to get rid of me for years-they've never loved me" may hide more complex emotions and attitudes. It is only with some understanding of these complexities that the lawyer can help the client determine what course of action is best suited to his or her interests. Thus, the lawyer must above all be a perceptive listener.

Once the attorney lias ascertained what the client wants to do about the proposed commitment, he or she has the obligation to present these wishes im as effective a manner as possible. ${ }^{277}$ If the child's desire is to contest the proposed lospitalization, the first forum in which the attorney should present the client's wishes is a negotiation conference with the parents and hospital staff. It may be possible to agree upon a less restrictive alternate setting in which the child can receive treatment. Or the hospital staff may be persuaded that it is only the child's presence in the family situation that is causing the disruption, and that placement in a group home or emancipation would solve the problem. If an alternative to hospitalization is agreeable, the attorney should explore possible sources of fimancial support for the client in such a setting.

Even if these negotiations are unsuccessful, the information they provide may be a useful form of pretrial discovery as the attorney prepares to represent the child's interests in a second forum-the courtroom. In the hearing, the lawyer will in most cases want to examine the parents as witnesses in order to explore their reasons for seeking the child's commitment, their perceptions of the child's problems, their

277. See Andalman \& Chambers, supra note 239 , at $46-54$. 
relationship to the family's problems. It will also be important to present the proposed patient as a witness, since the judge will be unwilling to overrule the wishes of the parents and the judgment of the psychiatrists unless he or she is convinced that the child can successfully handle some other arrangement. The inost crucial part of presenting the client's case at a juvenile commitment hearing inay often be the cross-examination of the psychiatrists who are recommending commitment. ${ }^{278}$ Often it will be valuable to present the testimony of other psychiatrists or mental health professionals who have interviewed the chent and who do not behieve commitment is required.

If commitment is ordered by the judge at the conclusion of the hearing, or if the client decides not to contest the commitment, there are other functions which the lawyer should perform. One is to help the chient settle any personal affairs which may be affected by hospitalization-things which may range from taking care of a car to arranging a smooth withdrawal from school, protecting if possible the right to re-enroll when hospitalization has ended. There may also be financial arrangements which have to be made-providing for installment payments which may be due, adjustimg any property or trust interests the client may have, and most important, determining how the cost of hospitalization is to be met.

Finally, while the lawyer should try to avoid becoming a middleperson in future power struggles between the client and the hospital (or parents) because of the detrimental impact that imght have on the client's acceptance of ordered treatment, it is appropriate for the attorney to reassure the client that counsel will again be available at the time of the periodic review of commitment, and may also be available if problems arise concerning in-hospital civil liberties. ${ }^{270}$ The knowledge that there is someone on the "outside" who is concerned about his or her fate after lospitalization may be one of the most valuable things a lawyer can give to a child-chent.

\section{VII}

\section{Alternative Dispositions for ChILDREN Who ARE Not HosPITALIZED}

Home is where, when you go there, they have to take you in.

While parents may incorrectly conclude that their child requires psychiatric hospitalization, they may be entirely correct when they de-

278. A useful guide in preparing for such cross-examination is J. Ziskin, CopiNo with Psychiatric and Psychological Testimony (1970). See also A. Watson, PsyCHIATRY FOR LAWYERS 305-10 (1968).

279. See Ferleger, Loosing the Chains: In-Hospital Civil Liberties of Mental Patients, 13 Santa Clara Law. 447 (1973). 
cide that they can no longer tolerate the child's behavior. ${ }^{281}$ The conclusion may be the same even though the child is not the major contributor to the family pathology. ${ }^{282}$ Thus, under the proposed system of judicially scrutinized juvenile commitments, the family may be unwilling to take the child back into the family home when the petition to commit the child is denied.

The problem of alternative disposition arises when the court demies the parents' petition for commitment, when the child's request to withdraw from the hospital is granted, or when the child is released after a hearing required by a periodic review statute. In none of these situations does the court's decision solve the family problems which nay have prompted the parents to seek the child's commitment. For whatever reasons, some families refuse to accept a meinber who has been discharged from a mental hospital; this is especially true for lowmconve families ${ }^{283}$ and in cases of extended hospitalization. ${ }^{284}$ Simce children are often economically and emotionally ill-equipped to fend for themselves, some individual or institution will have to assume the familial function if the child's right to contest his or her hospitalization is to be meaningful. ${ }^{285}$

One count recently faced this situation in a case imvolving children who, prior to their hospitalization under a voluntary juvenile statute, had been wards of the state. In In re Lee, ${ }^{286}$ the court concluded that the children's right to seek their own discharge was abridged by the lack of dispositional alternatives available to them, and that therefore the state had an obligation to find suitable placements for the children who had successfully contested their hospitalization.

In Lee, the state had a pre-existing duty to care for the children as wards of the juvenile court. The state may have no such encom-

280. R. Frost, The Death of the Hired Man, in ROBERT Frost: POETRY AND Prose 17-22 (E. Lathem \& L. Thompson eds. 1972).

281. See text accompanying notes 57-61, supra.

282. See text accompanying notes $112-27$, supra.

283. T. LDz, supra note 63, at 130. See also Whatley, Social Attitudes toward Discharged Mental Patients, in The Mental. Patient: Studies in the Sociology of Deviance 401 (S. Spitzer \& N. Denzin eds. 1968); Crocetti, Spiro \& Siassi, Are the Ranks Closed? Attitudinal Social Distance and Mental Illness, 127 AM. J. PsYcerat. 112 (1971).

284. Pokorny \& Bentinck, A Study of Relatives Views of State Mental Hospital Patients, 50 Social. CaSEwORK 519, 525 (1969).

285. It has been held that the state cannot continue to hospitalize a person no longer in need of treatinent on the grounds that his or her relatives refuse to accept him or her into their homes. Application of the Director of Creedinore State Hosp., 62 Misc. 2d 830, 310 N.Y.S.2d 22 (Sup. Ct. 1970).

286. No. 68 (JD) 1362 (Cook County Cir. Ct., Juv. Div., Ill. Aug. 24, 1972) (ordering the preparation of plans for placement of discharged children and requiring inonthly reports evaluating each ward's progress) abstracted in 6 CLEARINGHOUSE REv. 575 (Jan. 1973). 
passing pre-existing duty when children are committed by their parents. But courts could impose an obligation on the state when parents are unwilling to take a judicially-released child back into the home. One model for such judicial dispositional power can be found in statutes giving juvenile courts jurisdiction over dependent and neglected children. ${ }^{287}$ Assistance in finding alternate dispositions for children whose commitment petitions are denied could be required of the child's attorney and the hospital staff. When the child is in need of psychiatric treatment-but not commitment-the court may opt for placement with a community mental health center, ${ }^{288}$ or in a group home, half-way house, or foster home. ${ }^{289}$ Partial or total emancipation may be appropriate for teenagers who do not require close supervision. ${ }^{200}$

Court inquiry into alternative living and treatment situations has been required by some judges and legislatures in the case of adult inental patients. In Lake v. Cameron ${ }^{201}$ the Court of Appeals for the District of Colunbia held that alternatives less restrictive than confinement must be considered in habeas corpus proceedings. ${ }^{202}$ In Covington v. Harris ${ }^{203}$ the same court implied that the inquiry into less restrictive alternatives required under the District of Columbia statute

287. E.g., CAL. Welf. \& INST'NS CODE $\$ 600$ (West 1972).

288. For a description of some of these facilities, and of crisis intervention centers, see Wexler, supra note 246, at 118-46.

289. However, growth of the community mental health movement could lead to an undesirable expansion of the class of persons subjected to compulsory treatment. Bleicher, Compulsory Community Care for the Mentally Ill, 16 Clev.-Mar. L. Rev. 93, 102 (1967). Arguably, since care in an outpatient treatment facility involves far less drastic infringements of the patient's biberty than does hospitalization, the procedural safeguards and strict standards of proof required for commitment are unnecessary. In practice, this would expand the class of persons subject to involuntary, non-institutional treatment to include those who would benefit from such treatment but who do not meet the stricter standard of dangerousness to themsclves or to others. In most states, compulsory hospitalization can already be ordered for non-dangerous persons found to be "in need of treatment," and the increasing availability of less restrictive facilities may encourage this trend.

For a comparative discussion of various bases for civil commitment (e.g., "need of treatment," danger to self, or danger to others), see Note, Civil Commitment of the Mentally Ill: Theories and Procedures, 79 HARv. L. Rev. 1288 (1966); Livermore, Malmquist \& Meeml, On the Justifications for Civil Commitment, 117 U. PA. L. REv. 75 (1968).

290. In re Cameron M., (P. Ct., Dist. of New Haven, Conn. Jan. 1974).

291. 364 F.2d 657 (D.C. Cir. 1966).

292. Ms. Lake suffered froin senility and forgetfulness. Although she posed no danger to others, she was confined to a mental hospital for her own protection. The demial of her writ of habeas corpus was reversed because the District Court failed to consider less restrictive alternatives as required by a local statute. Some alternatives suggested by the court did not involve "treatment." Since Ms. Lake's problem involved absent-minded wandering, the court suggested that wearing an identification tag would be sufficient protection. Id. at 661 .

293. 419 F.2d 617, 623 (D.C. Cir. 1969). 
in Lake was also constitutionally required under due process. Such a right is consistent with constitutional requirements for less restrictive alternatives in other situations, ${ }^{294}$ and may have therapeutic value since mental health professionals generally believe that persons suffering from mental illness respond best to care provided in nominstitutional environments. ${ }^{295}$

The arguments for requiring that adult patients be treated in the community or in settings which do not unnecessarily restrict their liberty should also be applicable to juveniles. However, a child's right to live without continual supervision has not been judicially recognized. While children normally are in the custody and control of their parents or guardians, ${ }^{296}$ it is clear that the courts have the power to assume the supervision of children in order to protect the public interest. Juvenile courts often require noninstitutional treatment of children who have been adjudicated "in need of supervision," 297 and extending this power to the juvenile commitment situation will give the courts greater incentive to refuse authorization of unnecessary commitunents to mental hospitals. A conscientious judge faced with only two choices-hospitalization or no treatment for the child-may err on the side of hospitalization. If commitment is demied, the court should have jurisdiction to order alternative treatment or living arrangements which are appropriate for the individual..$^{298}$

In a recent study of the child custody problem, Joseph Goldstein, Anna Freud, and Albert J. Solnit have suggested several concepts which are useful while analyzing institutionalization and alternatives. ${ }^{299}$ The first of these is the crucial importance of an ongoing relationship with at least one adult who assumes a parental role. ${ }^{300}$

294. See, e.g., Shelton v. Tucker, 364 U.S. 479, 488 (1960) (state law infringing freedom of association struck down where "less drastic means for achieving the same basic purpose" existed); Dean Milk Co. v. City of Madison, 340 U.S. 349, 354 (1951) (local ordinance which burdened interstate commerce struck down because "reasonable and adequate alternatives [were] available"); Chambers, supra note 250, at 1145-51; Wormuth and Mirkin, The Doctrine of Reasonable Alternatives, 9 UTAH L. REv. 254 (1964).

295. Chambers, supra note 250 , at 1113.

296. Any right of parents to compel their children to undergo noninstitutional psychiatric treatment is beyond the scope of this Article. No cases have been fonnd which address this issue. But cf. In re Smith, 16 Md. App. 209, 295 A.2d 238 (1972) (holding that under state law a parent could not force her teenage daughter to have an abortion).

297. Solne states attach this label to their mcorrigibility statutes. E.g., N.Y. SoCial Welfare Law $\$ 371.6$ (West 1966).

298. Any alternative should be subject to the same automatic periodic review required in hospitalization cases.

299. J. Goldstein, A. Freud \& A. Solnit, Beyond the Best Interests of the CHILD (1973).

300. Id. at 17. 
One implication of this finding is that institutionalization of the child should be avoided whenever it is not absolutely necessary, and its duration sliould be minimized whenever possible. In the case of a seriously dysfunctional family, the parents nay not be filling that role, but in such cases, placing the child in a setting where some person will perform that role is clearly preferable to institutionalization. Another implication is that where such a role is established with a parent, but where serious problems lave arisen in the family, a family treatment approacli is preferable to one in which the child is removed from the home setting.

A second concept presented by Goldstein, Freud and Solnit is that the child's concept of time may be greatly different than that perceived by adults. ${ }^{301}$ What might seein to be a relatively short time for adults may be excruciatingly long for a child-especially a young child. Simce institutionalization has a particularly harmful inpact on children, the fact that such a stay in the hospital is perceived as being very long makes the impact even worse. A time limit should be placed on the duration of a child's involuntary stay in a hospital unless the commitment is based on dangerousness, and in any event, the amount of time in the lospital should be kept to the minimum necessary period in any indivdiual case. In pursuit of that goal, periodic judicial review of commitments is required at fairly frequent intervals. While it might be argued that such frequent disruption of the therapeutic process in order to call into question the hospitalization itself might be countertherapeutic in many cases, such considerations are outweighed by the importance of keeping hospitalizations of all children as short as possible, and to reassure the child at frequent intervals that he or she lias not been forgotten-that there are those on "the outside" who contimue to be concerned about the child's fate and who are looking after his or her interests.

Finally, the authors of the study contend that the traditional goal in juvenile cases of "the best interest of the child" is insufficient in light of these facts, and that it should be replaced with the standard of "the least detrimental available alternative for safeguarding the child's growth and developinent."302 It is hoped that by providing judicial scrutiny of decisions to commit children, and by trying to assure that alternative solutions short of institutionalization receive serious consideration in each case, this standard can be inet under a new system of juvenile commitments.

301. J. Goldstein, A. FreUd \& A. Solnit, supra note 299, at 40.

302. J. GoldsteIn, A. FREUd \& A. SolnIr, supra note 299 , at 53. 


\section{VIII}

\section{Constitutional Challenges to Voluntary Juvenile Commitment StatuTes}

The Supreme Court recently noted that: "Considering the number of persons affected, it is perhaps remarkable that the substantive constitutional limitations or this [commitment] power have not been more frequently litigated. ${ }^{303}$ The only Supreme Court cases dealing with commitment of persons suspected of mental illness have involved defendants originally incarcerated as criminals or under quasi-criminal procedures for mentally defective sex-offenders. ${ }^{304}$ The courts appear more comfortable applying established criminal procedures, than formulating new standards for those whose only alleged "crime" is their craziness. The rights of the mentally ill have been extended by equal protection comparisons with the criminal procedure requirements of the Bill of Rights, but little attention has been paid to due process arguments when no obvious comparison to criminal cases presented itself. Juvenile voluntary commitment statutes may be more vulnerable to due process attacks than to equal protection challenges. Opponents of the existing juvenile commitment process should focus on the many procedural defects of that system rather than merely urging the application of the fairer, but still inadequate, system already applied to other classes of cases. This section briefly discusses the equal protection and due process arguments available to opponents of the current juvenile voluntary commitinent system.

\section{A. Equal Protection}

An equal protection analysis of parental commitnent of juveniles must begin with a determination of the classes to be compared. The complaining class would be potential juvenile patients subject to "voluntary" commitinent at the request of their parents. The adult class with whom the juveniles are to be contrasted may be composed of either adult voluntary patients or adult patients who have been committed involuntarily. If voluntary patients are chosen, the claim would be that juveniles were denied equal protection when they were committed witliout their informed consent, since all adults admitted under the statute nuust consent to admission. Furthermore, although technically "voluntary patients," juveniles are demied the right to re-

303. Jackson v. Indiana, 406 U.S. 715,737 (1972) (footnotes omitted).

304. Chambers, supra note 250. E.g., Jackson v. Indiana, 406 U.S. 715 (1972); Humphrey v. Cady, 405 U.S. 504 (1972); Specht v. Patterson, 386 U.S. 605 (1967); Baxstrom v. Herold, 383 U.S. 107 (1966); and the earliest Supreme Court case on the subject, Minnesota ex rel. Pearson v. Probate Court, 309 U.S. 270 (1940). 
quest their own release-a right afforded to all adult voluntary patients. If involuntarily committed adult patients were to constitute the comparison class, juveniles could claim that they were demied equal protection when they were not afforded procedural rights granted to adults similarly hospitalized against their will. Such rights might include notice and hearing requirements, rights within the commitment proceedings themselves, and any post-commitment rights to periodic review, habeas corpus, or automatic release recognized by a given state.

Another equal protection approach would be for juveniles admitted under voluntary statutes to claim they were demed rights accorded to adults patients generally, thus forcing the state to elect whether to proceed under the adult voluntary patient statute-requiring the child's consent to hospitalization and preserving the right to subsequently request discharge- or under the adult involuntary patient statute-im which case adult involuntary commitment procedures would apply. Putting the state to such an election would give the advantage of admission and treatment while preserving the right to seek release. But the election raises the problem of determining which children are appropriate for the voluntary proeedures (with release possibilities) and which should be subjected to the closer scrutiny of involuntary commitunent procedures. A successful challenge on any of these equal protection comparisons is likely to have identical results: If the child objects to hospitalization or requests release froin an institution, and if the state or the parents persist in seeking or continuing hospitalization, the imvoluntary commitment procedures-or something closely resembling them-would be employed to determine whether the child could be hospitalized against his or her will.

\section{Challenging Juvenile Commitments under the "Rational Basis" Test}

Absent a finding of a "suspect classification" or "fundamental interest," juvenile patients are demied equal protection of the laws only if there is no "rational basis" for the state's decision to treat the admission of adult and juvenile mental patients differently. ${ }^{305} \mathrm{~A}$ nun1ber of arguably legitimate state purposes can be put forward as the basis for distinguishing between children and adults in commitment proceedings: the need to provide hospitalization for those too young to seek help themselves, the recogmition of parental interest in procuring treatment for the mentally ill offspring, or the importance of pro-

305. Developments in the Law-Equal Protection, 82 HARv. L. REv. 1065, 1076 (1969). 
viding mental health care at an early age when it may have the greatest chances of success. Since the state is required to show only a veneer of rationality under this test, any of these state interests would probably be held sufficient to justify different commitment procedures for adults and juveniles.

\section{Testing Juvenile Commitments under a "Compelling State Interest" Test}

This test is used when the state employs a suspect classification or infringes on a fundamental interest of the disadvantaged class. The state must demonstrate that its objective cannot be met in a nondiscriminatory manner, and that the benefit gained by the measure outweighs the detriment suffered by the class which is the subject of the discrimination. Defenders of the existing juvenile commitment system would be hard pressed to show that a state's interest in denying children any judicial scrutiny over the commitment decision is compelling. Since hearings and other advantages of due process are provided for adult mental patients, it would be difficult to prove that putting a child through the "ordeal" of a hearing is a vastly inore dangerous and countertherapeutic process. It would be equally difficult for the state to prove that there is no practical alternative by which it could provide mental health services for young people, or that there is no other feasible way to resolve family disputes about whether the child needs hospitalization. The state's interest in giving parents total discretion over the hospitalization of their children has never been carefully articulated, and even when reasons are suggested, they hardly appear coinpelling.

In view of the attractiveness of the compelling state interest test, it will be important to argue its applicability to the challenge. One contention might be that age is a suspect classification. Discriminations on the basis of race, ${ }^{306}$ alienage, ${ }^{307}$ and $\operatorname{sex}^{308}$ have been held to require a compelling state interest. Like recognized suspect classes suffering discrimination, children have been excluded from participation in community affairs and are politically disadvantaged..$^{309}$ But unlike other groups which have been granted constitutional protection, children cannot claim that a history of discriminatory legislation indicates

306. E.g., Loving v. Virginia, 388 U.S. 1 (1967).

307. E.g., Takahashi v. Fish and Game Comm'n, 334 U.S. 410 (1948).

308. Four Justices of the United States Supreme Court held sex to be a suspect classification in Frontiero v. Richardson, 411 U.S. 677 (1973). The California Supreme Court found sex a suspect classification in Sail'er Inn, Inc. v. Kirby, 5 Cal. 3d 1, 485 P.2d 529, 95 Cal. Rptr. 329 (1971).

309. Cf. United States v. Carolene Prod. Co., 304 U.S. 144, 153 n.4 (1938). 
that childhood is viewed as a badge of opprobrium. ${ }^{310}$ Neither can it be argued that childhood is a permanent condition. ${ }^{311}$ The most persuasive argument against treating children as a suspect class is a practical rather than doctrinal one: While the political disabilities of children are real and obvious, such a ruling might jeopardize all laws which treat children and adults differently. On a whole range of issues-imcluding support, education, and employment-there is wide social consensus that children should not be subject to the saine laws as adults. While some of these laws may be unwise and mjurious to the real interests of children, or unconstitutional on other grounds, a declaration that the state can treat children differently from adults only in the most extreme circumstances is a weapon far too blunt for the correction of these injustices.

Therefore, a more likely way of triggering the compelling state interest test is by a showing that the discrimination infringes a fundamental interest of the child who is unwillingly hospitalized. Recognized fundamental interests include voting, ${ }^{312}$ procreation, ${ }^{313}$ interstate travel, ${ }^{314}$ and the procedural rights of criminal defendants. ${ }^{315}$ The common thread running through these fundamental interests seens to be the severity of the detriment imposed on the coinplaining party. ${ }^{310}$ While a standard based on muposed detriment may be imprecise, it would be difficult to argue that being involuntarily locked up in a inental institution is not a sufficiently severe detriment to warrant close judicial scrutiny of a discriminatory system. Recogmition that criminal procedures involve a fundamental interest ${ }^{317}$ is based primarily on a similar deprivation of physical liberty and imposition of lasting social stigma. The constitutional status of involuntary incarceration should not depend upon whether the victim is confined in a prison or in a mental hospital. ${ }^{318}$ The deprivation of personal liberty that results from confineinent in a inental hospital should require a compelling state interest to justify any discrimination. ${ }^{310}$

310. Developments in the Law-Equal Protection, 82 HaRv. L. Rev. 1065, 1127 (1969). While opprobrium does not attach to being a child, legal inferiority is attached to the status.

311. Id. at 1126. See also Note, Mental Illness, A Suspect Classification?, 83 YALE L.J. 1237 (1974).

312. E.g., Harper v. Virginia Bd. of Elections, 383 U.S. 663 (1966).

313. E.g., Skinner v. Oklahoma ex rel. Williamson, 316 U.S. 535 (1942).

314. E.g., Shapiro v. Thompson, 394 U.S. 618 (1969).

315. E.g., Griffin v. Illinois, 351 U.S. 12 (1956).

316. Developments in the Law-Equal Protection, 82 HARv. L. REv. 1065, 1130 (1969).

317. Douglas v. California, 327 U.S. 353 (1963).

318. Heryford v. Parker, 396 F.2d 393, 396 (10th Cir. 1968).

319. [T]he fact that the curtailment of liberty by civil commitment is so total and that civil-commitment legislation does not by its terms refer to 


\section{Challenging the Juvenile Commitment System Under an \\ "Intensified Means Scrutiny" Test ${ }^{320}$}

Under this test, the court would avoid intensive examination of the goals of state legislation and instead direct its scrutiny toward the reasonableness of the inethods used by the state to achieve those goals. ${ }^{321}$ The court could find that the state might reasonably encourage hospitalization of mentally ill juveniles, and could use different procedures for juveniles and adults to achieve this goal. But any intensified scrutiny of the present juvenile voluntary system will reveal that the means developed by the state are unduly restrictive because the state's goal can practicably be accoinplished without completely curtailing the rights of juvenile patients. This judicial approach seems better suited to the juvenile commitment problem than either the rational basis test or the compelling state interest test. Considerations involved in the proposed hospitalization of a child inay differ from the adult admission situation. Because of the potential for parental intimidation of children, the state might well provide for judicial inquiry into the real wishes of a child who "agrees" to hospitalization. The ineans scrutiny test would permit reasonable state responses to such differences. The means scrutiny test would also prevent the judiciary from overlooking the vast discrepancies between adult and children's rights under the present system.

\section{The Applicability of Equal Protection Analysis to the Juvenile Commitment System}

The courts have frequently used the equal protection clause to strike down laws relating to the inentally ill. The leading Supreme Court case is Baxstrom v. Herold, ${ }^{322}$ in which a prisoner had been administratively committed as insane toward the end of his prison term. The Court noted that this administrative procedure bypassed the state's guarantee of a jury trial on the issue of commitability, and held that "the State, having made this substantial review proceeding gen-

\footnotetext{
"travel," to "association," or to sexual relations with one's spouse may, by some ironic and inappropriate process, appear to make such rights irrelevant to an analysis of the issues surrounding civil commitment. Much the same problem is posed in discussing the seriousness of a policeman's killing of a fleeing suspect in terms of its impact on the suspect's right to trial by jury. Perhaps an unconscious desire to deny the impact of confinement (or killing) leads us to refuse to think seriously about the loss of freedom involved.
} Chambers, supra note 250, at 1162.

320. Gunther, The Supreme Court 1971 Term, Forward: In Search of Evolving Doctrine on a Changing Court: A Model for a Newer Equal Protection, 86 HARv.

L. REv. 1, 24 (1972).

321. Id.

322. 383 U.S. 107 (1966). 
erally available on this issue, may not, consistent with the Equal Protection Clause of the Fourteenth Amendment, arbitrarily withhold it from some."323 Other courts have relied upon Baxstrom and the equal protection clause in striking down procedures used to commit, as insane, those acquitted of crimes, where the procedures were substantially less rigorous than those in civil commitment proceedings. ${ }^{\text {n2t }}$ Only one case lias been found in which a court used an equal protection analysis to grant rights to one class of non-criminal mental patients which had previously been granted to another class of civil patients. In that case, the New York Court of Appeals held that a civil patient administratively transferred from involuntary to voluntary status was denied equal protection of the laws because "voluntary" patients lacked the substantive rights of involuntary patients. ${ }^{325}$

Despite the seeming applicability of these same equal protection arguments to juveniles admitted under voluntary statutes, two factors make equal protection a less than perfect vehicle for challenging the constitutionality of these laws. First, the courts may be reluctant to use equal protection because, even if age is not declared a suspect classification, courts may fear setting precedents for later cases contesting the many laws which treat children and adults differently.

The other problem with an equal protection challenge is that it might prove to be a hollow victory for the child, since in many jurisdictions, the rights of adult mental patients have been left undefined by the court. Thus, the winner of an equal protection challenge who achieved equality with adult patients might find that the state's adult commitment statutes provide few procedural protections. A related problem is the vulnerability of equal protection rights, for as one jurist has noted, reliance on equal protection to extend procedural rights to new classes of mental patients implies that the legislature has the power to avoid the problem by withdrawing those rights front everyone. ${ }^{320}$

Despite these drawbacks, equal protection has one advantage for the hitigant challenging these laws. Equal protection arguments allow the plaintiff to demonstrate the stark contrast between juvenile rights and those enjoyed by adults in a particular jurisdiction. Thus, it would be sound strategy for those challenging juvenile commitment statutes to include equal protection arguments-perhaps emphasizing the means scrutiny approach —along with any due process challenge. ${ }^{327}$

323. Id. at 111. See Humphrey v. Cady, 405 U.S. 504 (1972).

324. United States ex rel. Schuster v. Herold, 410 F.2d 1071 (2d Cir. 1969); Bolton v. Harris, 395 F.2d 642 (D.C. Cir. 1968).

325. In re Buttonow, 23 N.Y.2d 385, 244 N.E.2d 677, 297 N.Y.S.2d 97 (1968). The opinion also rested on due process grounds.

326. Id. at 394, 244 N.E.2d at 682, 297 N.Y.S.2d at 104 (Keating, J., concurring).

327. Rejecting Justice Black's suggestion that equal protection was also an appro- 


\section{B. Due Process}

The current juvenile commitment system contains no due process protections. No notice, no hearing, no counsel, no cross-examination, no witnesses are required. No burden or standard of proof exists because nothing need be proven. Once due process is seen as an appropriate direction for imquiry regarding the constitutionality of the system, the imquiry necessarily focuses on what due process elements should be required. The most fruitful starting point would appear to be the procedural rights of nonjuvenile mental patients.

The Supreme Court has never defined the due process rights of mental patients, but the undeniable similarity between involuntary commitment and criminal imprisonment has been noted by many authorities. ${ }^{328}$ The Suprente Court has forbidden the state to deny procedural rights simply by labelling the proceedings and subsequent incarceration "civil" rather than "criminal."329 This rule has been held applicable to a mentally retarded child institutionalized in what was called a school for the feeble-minded. ${ }^{330}$ There is no reason to view differently a child locked up im an institution called a inental hospital.

For a time, the most sweeping lower court decision on the due process rights of nental patients was Lessard $v . S c h m i d t,{ }^{331}$ in which

priate basis for decision, the Supreme Court relied upon due process to extend protection to children in juvenile delinquency proceedimgs. In re Gault, 387 U.S. 1 (1967). Due process standards allow the states some flexibility while requiring procedures which guarantee a basic level of fairness. Still majority opinion is replete with comparisons between adults' rights in criminal proceedings and the lack of similar rights in juvenile proceedings.

328. E.g., E. Goffman, Asyuums (1968); T. Szasz, Psychiatric Justice 238-41 (1965). The foremost authorities on the subject also agree: "Many of the patients ... do not consider it a lospital but rather a prison, and an extremely undesirable prison at that." Hess \& Thomas, Incompetency to Stand Trial: Procedures, Results and Problems, 119 AM. J. Psychiat. 713, 720 (1963).

329. In re Gault, 387 U.S. 1 (1967). The Court exalted substance over form:

The boy is committed to an institution where le may be restrained of liberty for years. It is of no constitutional consequence-and of limited practical meaning-that the institution to which he is committed is called an Industrial Scliool. The fact of the matter is that, however euphemistic the title, a "receiving lome" or an "industrial school" for juveniles is an institution of confinement in which the clild is imcarcerated for a greater or lesser time. His world becomes "a building with whitewashed walls, reginiented routine and imstitutional lours . ..." Instead of mother and father and sisters and brothers and friends and classmates, his world is peopled by guards, custodians, state employees, and "delinquents" confimed with hin for anything from waywardness to rape and homicide.

In view of this, it would be extraordinary if our Constitution did not require the procedural regularity and the exercise of care implied in the phrase "due process."

Id. at.27-28 (footuotes omitted).

330. Heryford v. Parker, 396 F.2d 393 (10th Cir. 1968).

331. 349 F. Supp. 1078 (E.D. Wis. 1972), vacated and remanded on other grounds, 94 S. Ct. 1078 (1974). 
a three-judge federal court struck down Wisconsin's civil commitment statute because prospective patients were denied various due process rights. ${ }^{332}$ The Lessard court found it constitutionally impermissible to detain a patient in a hospital for a significant period of time without a hearing ${ }^{333}$ and required that patients be given notice of the mandatory hearing. ${ }^{334}$ The court ruled that the standard for finding commitment necessary should be "beyond a reasonable doubt" and not merely "by a preponderance of the evidence,"335 that full-time involuntary hospitalization should be ordered only when less drastic means are not available, ${ }^{336}$ that the burden of proof must be on the party recommending hospitalization, ${ }^{337}$ that the patient has a right to appointed counsel, ${ }^{338}$ that the patient's statements could not be introduced by the state unless the patient knew she had the right to remain silent, ${ }^{339}$ and that the standard rules of hearsay should apply in a civil commitment hearing. ${ }^{340}$ Although the court thought the presence of counsel at the psychiatric interview was not necessary to assure that the patient understood the privilege against self-incrimination, it estabhished due process rights basically parallel to those guaranteed in criminal proceedings.

While these rights had been individually extended to inental patients in other cases, ${ }^{341}$ Lessard was generally viewed as the most authoritative judicial exposition on due process in civil commitments. Therefore, the Supreme Court's order vacating and remanding Les$\operatorname{sard}^{342}$ has created considerable uncertainty. While the reniand does not appear to go to the merits of the decision, the Supreme Court may have felt the district court had gone too far. If so, one can only specu-

332. Id. at 1103 .

333. Id. at 1090 .

334. Id. at 1092 .

335. Id. at 1093 .

336. Id. at 1095 .

337. Id. at 1096 .

338. Id. at 1097 .

339. Id. at 1101 .

340. Id. at 1103 .

341. E.g., In re Ballay, 482 F.2d 648 (D.C. Cir. 1973); Heryford v. Parker, 396 F.2d 393 (10th Cir. 1968); Dixon v. Attorney General, 325 F. Supp. 966 (M.D Pa. 1971); Denton v. Commonwealth, 383 S.W.2d 681 (Ky. 1964).

342. 94 S. Ct. 1078 (1974). The injunction against further commitments under the invalidated statute was not sufficiently specific. More recently, another three-judge Federal District Court issued a Lessard-like decision regarding Michigan's commitment laws, bnt avoided granting injunctive relief. Bell v. Wayne County General Hospital, - F. Supp. - (E.D. Mich., Consol. Civil Action No. 36384, June 4, 1974). A state court also reached a similar result in South Dakota. Schneider v. Radack (South Dakota Circuit Conrt, 1st Jud. Dist., May 3, 1974, unreported decision on file with the Mental Health Law Project, 1751 N Street, N.W., Washington, D.C., 20036). 
late about what the Justices had in mind, especially since the lower court's opinion covered so many issues.

Though the precedential value of Lessard may be impaired, precedent remains for the proposition that criminal due process standards must be approximated in civil commitment cases. In Dixon v. Attorney General of Pennsylvania, ${ }^{343}$ another three-judge federal court found many of the Lessard procedures to be constitutionally required. Several federal Circuit Courts of Appeals have similarly required particular due process protections, ${ }^{344}$ and several Supreme Court cases have extended due process rights to adult mental patients. ${ }^{345}$

The analogy to criminal law is not a perfect one; some of the procedures required in criminal cases may be mappropriate for civil commitment. ${ }^{346}$ But such exceptions, if they exist, should be justified by persuasive reasons. For example, Gault $t^{347}$ established that in juvenile court proceedings, children are entitled to notice of the charges against them, the right to counsel, the right to confront and cross-examine witnesses, and the privilege against self-imcrimination, ${ }^{348}$ but the Court later held that due process did not require the right to a jury trial in juvenile court, because that particular right might be mcompatible with the operations of that court. ${ }^{349}$ Similarly, it has been argued that in civil commitment proceedings, due process should be "adapted" to the therapeutic needs of the patient. ${ }^{350}$ If this rationale is used to exclude any of the traditional due process protections in civil commitment cases, the right to a jury trial is probably the most "dispensable" and the most "countertherapeutic." 351 But aside from this possible exception, a long line of decisions has established that the due process requirements long applied in the criminal courts are also required by due process in civil commitment cases..$^{352}$

343. 325 F. Supp. 966 (M.D. Pa. 1971).

344. In re Ballay, 482 F.2d 648 (D.C. Cir. 1973); U.S. ex rel. Schuster v. Herold, 410 F.2d 1071 (2d Cir. 1969), cert. denied, 396 U.S. 847 (1969); Heryford v. Parker, 396 F.2d 393 (10th Cir. 1968).

345. See note 304 supra.

346. See text accompanying notes 350-53 infra.

347. 387 U.S. 1 (1967).

348. Id. at $33,41,55,56$.

349. McKeiver v. Pennsylvania, 402 U.S. 528 (1971). However, the right to jury trials may be constitutionally required iu commitment proceedings notwithstanding McKeiver. See In re Gary W., 5 Cal. 3d 296, 486 P.2d 1201, 96 Cal. Rptr. 1 (1971). 350. Kadish, supra note 12. Fewer commentators now argue that due process can be drastically curtailed or "streamlined" for civil commitment cases because procedural protections do not serve the therapeutic interest of the patient.

351. But see note 349 supra.

352. See, e.g., Minnesota ex rel. Pearson v. Probate Court, 309 U.S. 270 (1940); Barry v. Hall, 98 F.2d 222 (D.C. Cir. 1938); People ex rel. Sullivan v. Wendel, 68 N.Y.S. 948 (Sup. Ct. 1900). 
In conclusion, it should be noted that the two constitutional challenges most apphicable to the juvenile commitment situation-due process and the means scrutimy approach to equal protection-should lead to similar results. The means scrutiny test would invalidate the current system as unnecessarily restrictive of juveniles' rights in light of the state's purpose. Under due process, some variations from adult commitment procedure would be permissible, but the vast disparity between current procedures for hospitalizing children and adults would be invalidated. By either analysis, the existing system would be found wanting and the state would need to create a new system for juvenile commitments: ${ }^{353}$ one which varies from the adult system only where such variations are dictated by the different needs of children, ${ }^{354}$ and which provides procedural safeguards required by due process.

\section{IX}

\section{ALternative System For JUvenile COMMtTMENT}

An acceptable juvenile commitment system will take into account the developmental differences between adults and children, the child's family' situation, and procedural safeguards designed to protect the child's interests.

\section{A. Precommitment Hearing}

One way to ensure that every child has an impartial determination of his need for hospitalization is to require a judicial hearmg whenever hospitalization is sought. ${ }^{355}$ There are, however, disadvantages to such a system. A stressful and superfluous legal proceeding could not be avoided even if the child agreed to hospitalization. Voluntary admission laws enable adults to submit to hospitalization without a hearing. ${ }^{356}$ But juveniles committed under current voluntary statutes are not volunteering-rather they are being "volunteered" by their parents. ${ }^{357}$ When the juvenile actually desires hospitalization, there should be some mechanism by which he can avoid a full-fledged court hearing. Finally, a mandatory judicial hearing for every child,

353. If the existing system were struck down the state could still hospitalize children under the adult involuntary commitment statutes. However, the adult system may itself be unconstitutional and in any case does not consider the special needs of children.

354. If juvenile commitment procedures are made more rigorous, adult patients may have a valid equal protection claim.

355. This could be the practical result-at least temporarily-if voluntary juvenile admission statutes are declared unconstitutional, since adult involuntary commitment statutes would then be the only method by which children could be committed.

356. See text accompanying notes 17-19 supra.

357. See text accompanying notes 20-26 supra. 
whether or not he or she contests commitment, is likely to create an assembly line process of ritual hearings. Such empty exercises may actually diminish the attention judges would otherwise devote to cases in which the child objects to commitment.

\section{B. Delayed Commitment Hearing}

A second possible approach would allow parents to commit their children without judicial supervision, as under current statutes, but would permit the child to seek his or her own release after a minimum period in the hospital-perhaps ninety days. This system would attempt to balance the parent's interest in being able to seek treatment for the child against the child's interest in avoiding unnecessary hospitalization. This plan would also permit deferral of decision making until an observation period has elapsed, during which the hospital staff could consider the child's problems and needs more carefully than in a short pre-admission interview. This time might also be useful to the parents and child as a cooling off period, a time to gain perspective on the stressful events which led the parents to seek the child's hospitalization.

Providing compulsory precommitment hearings and child-imitiated release procedures would not prevent the unnecessary institutionalization of children who need no treatment. While the observation period might be kept quite short by adult standards, according to a child's sense of time even a few days in the strange and frightening surroundings of even the best mental hospital may be a terrifying and traumatic ordeal. Such an experience shonld be imflicted on a child only when absolutely necessary. In fact, a child who does not need hospitalization at the time of commitment may learn "crazy" behavior from the culture of the mental hospital..$^{358}$ Thus, a better plan would retain the advantages of this proposal but also prevent totally unnecessary hospitalizations from occurring in the first place.

\section{Waiver of Precommitment Hearing}

The child could be allowed to waive a formal hearing and consent to the hospitalization after consultation with an attorney. ${ }^{359}$ Safe-

358. See text accompanying notes $157-160$ supra.

359. Since the parents are usually antagonistic parties and since the child is considered incompetent to enter binding contracts and usually indigent, the court must appoint counsel. Such a practice may foster a corps of knowledgeable and experienced juvenile cominitment attorneys. Attorney's fees may be taxed to the parents. It is not unusual to bind parents by the acts of their children. See CaL. WELF. \& INST'NS CODE $\S 903$ (West 1966) (parents liable for institutionalization costs of delinquent child); In re Shaieb, 250 Cal. App. 2d 553, 58 Cal. Rptr. 631 (4th Dist. 1967). The role of the attorney is discussed in Section VI of this Article, supra. 
guards, such as retaining the right to seek release in a later hearing, should be provided to prevent this system from camouflaging a return to unbridled parental discretion. Therefore, an appointed attorney should certify to the court having jurisdiction in juvenile commitment cases that he or she has: 1) consulted with the child about the proposed commitment, 2) explained to the child both the right to contest the commitment and the possible alternatives to commitunent, and 3 ) ascertained that it is the true wish of the child to enter the hospital and forego a judicial proceeding. The child might be required to sign a document stating that he or she does not wish to contest the hospitalization. But the more inportant document would be the attorney's, smce it would record the child's feelings about hospitalization and attitude toward challenging the parents' wishes. If both documents indicate to the judge that the child really does not want to contest hospitalization, the judge would rule that the child has validly waived the right to a hearing and may be hospitalized.

\section{Postcommitment Judicial Review}

If a child waives the commitment hearing and later wants to be released from the hospital, a hearing should be mandatory if the release is contested. Such a deferred hearing would differ from the usual habeas corpus hearing in that the parties seeking to continue hospitalization, the parents or the hospital, should still carry the same risk of nonpersuasion. If the presumption against hospitalization and the right to a hearing were not relinquished by consenting to commitment, the child's initial decision would not be made to hinge on legal procedures.

The right to release should be conditioned on notice to the hospital of an intent to sign out. A similar notice requirement, three to ten days for exainple, is presently required of voluntary adult patients in many jurisdictions. During the notice period, the hospital staff and the parents may prepare to contest the child's release or they inay prepare living arrangements for the child-either at home or in some alternative living situation. ${ }^{360}$ Once the child files a notice of intent to leave the hospital and the hospital or parents file a notice of intent to contest the release, a hearing would be inandatory.

Just as a juvenile should not be allowed to waive his right to counsel prior to commitment, so hospitalization of a child should not go unreviewed for a long period of time, nor should judicial scrutiny depend on the child's uncounseled mitiative in submitting a notice of intent to seek release. The system should contain a provision for inandatory periodic review of all cases of committed children, regard-

360. See text at notes 282-302, supra. 
less of whether the commitment was initially contested. Adult commitment laws of some states contain such provisions, ${ }^{361}$ but they are even more necessary for children. Institutionalization can have a particularly damaging effect on children, ${ }^{362}$ and should be minimized. The child's perception of time ${ }^{363}$ also accentuates the need for periodic review; what seems like a relatively short hospitalization to parents and hospital staff may be experienced as a very long confimement by the child. Finally, children may be more susceptible to intimidation than adults and less likely to attempt to exercise their rights to release. Periodic review would require the hospital staff to justify the contimued confinement of the child and encourage the staff to use treatment methods which will withstand judicial scrutiny. And, not least important, it would give the child periodic reassurance that he has not been forgotten.

\section{E. Juvenile Initiated and Emergency Commitment}

Provision should also be made for two other methods by which juveniles could be admitted to mental hospitals. The first of these could go by the traditional name "voluntary admission," but since that term has taken on other meanings in the juvenile context, a better term might be "self-initiated admission." Older juveniles should be able to seek their own hospitalization without the consent of their parents. They should, however, always be advised of the alternatives to hospitalization, and some protection should be provided to assure that the initiative is really that of the child, and not of parents trying to avoid the procedural requirements of the proposed system of parentrequested juvenile commitments. Thus, the statute should require every juvenile seeking hospitalization to consult with counsel in the same manner as children whose admission is sought by their parents.

Finally, some provision should be made for emergency hospitalization when the child is in danger of harming himself or others. Competing considerations are involved. On the one hand, even the expedited procedures for juvenile admissions outlined above would require too much time for a child facing a real emergency. On the other hand, emergency commitment statutes have been grossly abused in the past. ${ }^{364}$ A not altogether satisfactory compromise, taking into account

361. The Mentally Disabled and the Law 164-66 (S. Brakel \& R. Rock eds. 1971). Such periodic review has proven perfunctory when it becomes strictly a medical procedure without judicial scrutiny. R. Rock, M. JACOBSON \& R. JANOPAUL, HosPITALIZATION AND Discharge OF the MENTALLy IlL, 218 (1968).

362. See text accompanying notes 157-64 supra.

363. See text accompanying note 302 supra.

364. Roth, Lerner \& Daley, Into the Abyss: Psychiatric Reliability and Emergency Commitment Statutes, 13 SaNTA Clara LaW. 400 (1973). 
the greater impact on children of both a serious psychotic expisode and involuntary hospitalization, would provide for an emergency commitment procedure similar to that establislied by the California Lanterman-Petris-Slort Act. ${ }^{365}$ It is essential to adapt such a provision to the child's perception of time, and to ensure that no "emergency" commitment extends for more than a few days without judicial scruținy.

\section{F. Alternatives to Commitment}

At each precommitment or postcommitment learing the court should review possible alternate treatment settings which would be less restrictive than the proposed or current hospitalization. If commitment is to be ordered or continued, the judge should make a specific finding that at the time of the hearing no alternative was available for the child. Exploration of alternatives to lospitalization at periodic intervals will encourage a more careful evaluation of the child's condition than if the hospital were merely required to denionstrate that the child was still in need of treatment.

\section{G. The Standard for Commitment}

It has been persuasively argued that involuntary commitment for reasons other than dangerousness to self or others-as where a patient is described as "in need of treatment"-is unconstitutional. . $^{300}$ While only nine states limit adult involuntary commitments to dangerousness, ${ }^{367}$ the argument against paternalistically institutionalizing people "for their own good" seems compelling when the people involved are adults. While some of the factors leading to this conclusion-limitations on the ability of psychiatrists to effectively treat, ${ }^{308}$ or even correctly diagnose, ${ }^{369}$ mental problenis-are equally applicable to juveniles, the " $m$ need of treatment" standard may be more appropriate for children. Treatment is more likely to be successful when the patient is young and the mental disorder is in its acute (early) stage. There is also a recognized public interest in the future of children. Such paternalism, where it does not run afoul of specific constitutional

365. CAL. WeLF. \& INST'NS Code $\S \S 5150,5152$ (West 1966).

366. N. Kurtrie, supra note 4, at 66-67. See also Lessard v. Schmidt, 329 F. Supp. 1078, 1093 (E.D. Wis. 1972), vacated and remanded on other grounds, 94 S. Ct. 1078 (1974).

367. The Mentally Disabled and the LaW (S. Brakel \& R. Rock eds. 1971), supra note 365 , at 36 .

368. See Schwitzgebel, The Right to Effect Treatment, 62 CalIf. L. Rev. 936 (1974) (this issue).

369. See Ennis \& Litwack, Psychiatry and the Presumption of Expertise: Flipping Coins in the Courtroom, 62 CALIF. L. Rev. 693 (1974) (this issue). 
prohibitions, is supported by considerable authority. ${ }^{370}$ Children could be committed under the "in need of treatment" standard, but no child committed under that standard should have treatment continued involuntarily for more than six months. By comparison, under a dangerousness standard a child might be hospitalized beyond that time limit if necessary. This compromise recognizes that while the state and the parents have a strong interest in providing involuntary treatment for a child who needs it, this rationale loses force if the child is still unwilling after a period of months, because treatment is unlikely to be successful when the patient strongly and consistently opposes it. The child's opposition to treatment and hospitalization is also a more informed opposition when he or she has been in the treatment setting for a period of inonths, and therefore later opposition should arguably be given even greater weight than the child's imitial reluctance to enter the hospital. As with all time limits, the six nonth period is somewhat arbitrary, but even with children there must be some limitation upon paternalistic incarceration.

\section{H. The Standard of Proof}

Several courts have recently held that "proof beyond a reasonable doubt" is constitutionally required in civil commitment cases. ${ }^{371}$ The arguments advanced by these courts and various commentators are based on persuasive analogies to similar requirements in criminal cases. Sunilarly, while juvenile courts can obtain jurisdiction over children for incorrigible and predelinquent behavior, behavior which would not be criminal if committed by adults, sanctions in all cases must be based on proof beyond a reasonable doubt. ${ }^{372}$ When children are committed under a standard of behavior different than that required of adults, the standard of proof must remain at a high level. Arguments in favor of varying the standard of behavior should not be forced into double duty; they do not justify both relaxing the standard of commitment and enervating the standard of proof. Paternalism may justify early treatment of disturbed children, but is misplaced when it affects the precision required in proving that the need for treatment does in fact exist.

370. For a discussion of the parens patriae doctrine, see N. KITrRIE, supra note 4, at 3-9.

371. In re Ballay, 482 F.2d 648 (D.C. Cir. 1973); Lessard v. Schmidt, 349 F. Supp. 1078 (E.D. Wis. 1972), vacated and remanded on other grounds, 94 S. Ct. 1078 (1974). Cf. In re Winship, 397 U.S. 358 (1970), holding that proof beyond a reasonable doubt was required in juvenile court cases.

372. In re Winship, 397 U.S. 358 (1970). 
$\mathrm{X}$.

\section{Proposed Model Statute}

It has been argued in previous sections of this Article that the current system of juvenile commitments to inental hospitals unconstitutionally abridges children's rights. Thus much of the discussion has focused on litigation. But the task of devising a new system for pro. viding treatment to juveniles will fall to the legislatures. This Model Statute is an attempt to present a workable alternative to the present system, an alternative which considers the need of some children for involuntary treatment, the troubled situation in dysfunctional families, and the right of children to influence important events in their own lives.

\section{Section I. Purpose.}

The purpose of this Act is to prevent the involuntary hospitalization of minors except when treatment in a mental hospital is necessary. If treatment is required under the terms of this Act, and if there exist less drastio means of accomphishing therapeutic aims than hospitalization, those alternative means inust be employed instead of hospitalization.

\section{SeCtion II. Definitions.}

a. Minor and child shall refer to any person under the age of sixteen years. Any person over the age of sixteen shall come under the commitment and admission statutes which apply to adults.

b. Parent shall refer to the natural or adoptive parent of the child, if that person has custody of the child, or any other person who has de facto custody of the child.

c. Mental hospital shall refer to any facility, whether operated by federal, state or local government or by a private party or organiza* tion, which provides in-patient diagnostic and treatment services for mental and emotional disorders.

d. Mental health professional shall refer to any psychiatrist, psychoanalyst, psychologist, psychotherapist, psychiatric social worker, psychiatric nurse, or any other person whose professional occupation consists of dealing with the problems of the mentally ill. It shall also refer to any physician who is acting in a psychotherapeutic or counselling function. 
[e. Family Court shall refer to that court within a given jurisdiction which deals most frequently with family problems, such as marital, juvenile, and civil commitment matters.]

f. Imminent likelihood of serious harm to oneself means that it is more likely than not that in the near future the person will attempt to commit suicide or inflict serious bodily harm upon himself as manifested either (1) by behavior causing, attempting or threatening the infliction of serious bodily harm upon himself by violent means within thirty days prior to the filing of a petition for commitment or recommitment or (2) by nonviolent behavior which at the time the petition for commitment or recommitment was filed was currently causing serious bodily harm.

g. Imminent likelihood of serious harm to others means that it is more likely than not that in the near future the person will inflict serious, unjustified bodily harm on another person, as manifested by behavior causing, attempting to cause or threatening such harm, within thirty days prior to the filing of a petition for commitment or recommitment that gives rise to a reasonable fear of such harm from said person.

h. Mental disorder means a substantial disorder of the person's emotional processes, thought or cognition which grossly impairs judgment, behavior or capacity to recognize reality.

\section{Section III. Right to Institutionalization and Treatment.}

Nothing in this Act is intended to establish or restrict any right of minors to seek institutionalization or treatment over the objections. or without the consent, of persons having custody over them.

\section{Section IV. The Commitment Process.}

Any person having custody of a minor may seek to have that minor committed to a mental hospital only according to the provisions of this section.

a. Petition for commitment. The person seeking the commitment shall first file a petition for commitment of the minor with the Family Court.

b. Appointed Counsel. The Family Court shall, upon receipt of the petition, appoint counsel for the minor. The court shall give preference to any attorney selected by the child, but if the child declines to select an attorney, or if the selected attorney is unavailable, preference shall be given to attorneys who have experience in the areas of mental health or juvenile law. In no case shall the child's 
attorney be a person who has previously advised the person seeking the commitment of the minor or that person's business.

c. Representation by counsel. The child shall at all times, before and after commitment, be represented by counsel.

d. Attorney's interview. The child's counsel shall interview the child within two days after appointment by the Family Court, and shall investigate the situation thoroughly enough to make an informed judgment about the true intent of the child to either contest or accept the proposed commitment.

e. Waiver of hearing. If counsel for the child determines that it is the intent of the child to waive the right to contest the commitinent, counsel shall so declare in writing to the Family Court. A written statement verified by the attorney, describing the child's feehings about the proposed hospitalization shall accompany the attorney's declaration. If the Family Court, upon receiving such a statement and declaration from the child's attorney, is satisfied that the child has knowingly waived the right to a hearing, the child may be hospitalized. By waiving the right to a precommitment hearing, the child waives no other rights.

f. Psychiatric interview.

(1) The person seeking commitment of the child may designate in the petition for commitment a particular institution to which commitment is sought. The child will be interviewed by a inental health professional at this designated institution prior to the hearing for purposes of diagnosis and establishing a treatment plan, unless such an interview would substantially duplicate any recent and similar interview.

(2) The child shall lave the right to an interview with any mental liealth professional of his or her choice prior to the hearing. Upon the motion of the child, the court may order the person seeking commitment to pay an amount, in the discretion of the court, reasonable for a diagnostic interview, or in the case of fimancial hardship to such person, the count will order the cost paid from public funds.

(3) A written report of any interview, held at any time, between a child and a mental health professional shall be made available to the child's attorney.

g. Custody pending hearing. Pending the comunitment hear. ing, the child shall remain in the custody of the person seeking the commitment, except as provided under section IV(i) of this Act, and except that on noticed inotion, the Family Court may order the child placed in the custody of any other person, if the court finds such a change of custody would promote the best interests of the child. 
h. Scheduling of hearing. Unless a valid waiver is obtained in compliance with the terms of section IV(e) of this Act, a commitment hearing shall be held within ten days after the appointment of counsel, or within five days of a commitment of the child under section IV(i), whichever is earlier.

\section{i. Emergency commitment.}

(1) When any minor, as a result of a mental disorder, is imminently likely to cause serious harm to others or to himself or herself, a peace officer or any inental health professional may, upon reasonable cause, take, or cause to be taken, the child into custody and placed in a mental hospital, which shall require an application in writing stating the circumstances under which the child's condition was called to the attention of the person seeking the commitment, and stating that such person believes that the child is, as a result of mental disorder, imminently likely to cause serious harm to others or to himself or herself.

(2) The child shall be released if, at any time, in the opinion of the professional person in charge of the mental hospital, or a designee, the child no longer requires evaluation or treatment.

(3) If at the time of admission under this subsection a petition for commitment of the child is not pending, the following procedure shall be followed. The hospital shall file a petition for commitment pursuant to section IV(a) on the first working day after the admission of the child. The Family Court shall then immediately appoint an attorney pursuant to section IV(b). The attorney shall interview the child and investigate the circumstances of the child's admission as soon as possible. A commitment hearing shall be held within five days after the filing of the petition.

\section{Section V. The Commitment Hedring.}

a. Rights at the hearing. At the commitment hearing, the child shall at all times be represented by counsel; shall have the right to present witnesses in opposition to the commitunent, including inental health professionals; shall have the right to confront and cross-examine witnesses who favor the commitment; shall have the right to be personally present at the hearing; shall have a right to a written transcript of the proceedings and the right to an expedited appeal of an adverse ruling. The child shall have the right to testify or to remain silent, and cannot be forced to answer any question. Except as provided in this Act, the rules of evidence shall apply. The child shall also have any other rights required by the United States or State constitutions. 
b. Authority of the hearing judge to call and question witnesses. At the commitment hearing, the Family Court judge shall be empowered to call and question any witness, sua sponte, when the testimony of such a witness may assist the determination of the necessity of the proposed commitment.

c. Findings and order. The Family Court judge shall make an order committing or recommitting the child to a mental hospital only if it is shown beyond a reasonable doubt (1) that the child needs and will substantially benefit from treatment or is in imminent danger of causing serious harm to others or himself or herself; and (2) that no other means of treatment is feasible which involves less restriction of the child's liberty. No order of commitment shall be issued unless evidence has been admitted showing that no less restrictive alternative form of treatinent is feasible for the child. The court shall consider all possible treatment alternatives within the hospital as well as other treatment alternatives. If the court orders the commitment of the child, the order shall specify the treatment alternatives which the hospital may use.

d. Prompt adjudication. The Family Court judge shall determine in as short a time as possible whether the commitment is to be ordered. In no case shall the judge extend deliberations and postpone decision for a period exceeding ten days after the hearing. The decision shall be made within five days if, at the time of the commencement of the hearing, the child is in the custody of a mental hospital pursuant to section IV(i).

\section{Section VI. Periodic Judicial Review.}

a. Right to review. Every minor committed under this Act shall have the necessity and terms of his or her commitment reviewed by the Family Court in accordance with this section. Such review is a matter of right and is not waivable.

b. Commitment period. For the purposes of this Act, a commitment period shall be forty-five days, except that when the child attains the age of twelve, any commitment period commencing thereafter shall be ninety days. The first commitment period shall commence at the time the child is committed pursuant to this Act. Succeeding commitment periods shall commence at the termination of the preceding commitment period.

c. Hearing. If the hospital staff, or the person who sought the original commitment desires to have the hospitalization extended beyond the statutory commitment period, a petition for recommitment must be filed with the Family Court at least fifteen days before the expiration of the commitınent period. If such a timely petition is filed. 
a recommitment hearing, which shall conform to the specifications of sections IV and V of this Act, shall be held during the last ten days of the commitment period. After such a hearing, the judge shall order the child released unless the recommitment is shown to be necessary under the standards of section V(c).

SeCtion VII. Limitation on the Institutionalization of Minors Committed Because of Need of Treatment.

No child may be institutionalized im a mental hospital for a total of more than two commitment periods where the basis of the commitment order is that the child is in need of treatment, rather than proven imminent likelihood of serious harm to others or to himself or herself.

\section{Section VIII. Patient-Initiated Release.}

a. Form of notice. Notice of intent to withdraw nnay be given by any minor patient committed pursuant to this Act or his or her counsel. The notice need not follow any specific form so long as it is written and the intent of the child can be discerned. The notice may be written by a person other than the child if the child is unable to write it. The notice may be given to any staff member of the hospital. The staff member receiving the notice shall immediately date it, record its existence in the daily $\log$ of the ward and on the patient's medical chart, and send copies of it to: (1) the child's attorney; (2) the Family Court; and (3) to the parents or guardian of the child.

b. Uncontested releases The director of the hospital shall release the child from the hospital ten days after receipt of the child's notice, unless either the hospital or the parent or guardian files a notice of contest within the ten-day period. For such a notice of contest to be valid, copies must be personally delivered to the child, the child's attorney, the Family Court, the child's parent or guardian, and the hospital, prior to the expiration of the ten days following the child's notice of intend to withdraw.

c. Custody pending hearing. If a valid notice of contest has been received, the director of the hospital may refuse to release the patient until the Family Court orders otherwise. But in no case may the child be held more than fourteen days beyond the expiration of his or her ten-day notice unless a valid recommitment order has been issued by the Family Court.

d. Recommitment hearing. A hearing to determine the necessity for continued commitment shall be held within ten days of the court's receipt of the notice of contest. The learing will conform to the requirements of section $\mathrm{V}$ of this Act. After such a hearing, the 
judge shall order the child released unless the commitment is shown to be necessary under the standards of Section V(c).

e. Withdrawal of the child's notice. Once a child has submitted a ten-day notice to this section, it cannot be withdrawn, and a hearing must be held.

f. Limitation on child's notice rights. A child may not submit nore than one ten-day notice during any commitment period.

SeCtion IX. Attorney's Role During the Minor's Commitment.

a. Access to attorney. The child shall at all times have access to ineans of communication with his or her appointed attorney, and such communciations shall be privileged and secret from any other person, imcluding the parents and the hospital staff.

b. Replacement of attorney. When the child's appointed attorney is unavailable, the court shall appoint a new attorney pursuant to Section IV(b).

c. Power to petition. The attorney shall also be empowered to petition the court at any time regarding any unlawful conditions or practices at the hospital involving the child.

d. Access to the child. The child's attorney shall have the right to enter the hospital at any time to inspect conditions, or, at any time reasonable under the circumstances, to interview or observe the child.

\section{Section X. Parental Treatment.}

If a parent seeks, or causes any other person to seek, the commitment of a child imder this Act, the hospital and/or the Family Court may require that the parent participate in any reasonable program of family treatment or counselling as may be appropriate. No person inay be committed to a mental hospital under this section. 